


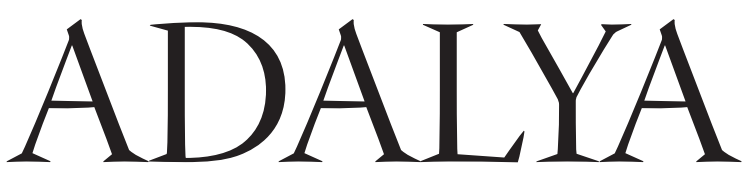

The Annual of the Koç University Suna \& İnan Kıraç Research Center for Mediterranean Civilizations

(OFFPRINT) 


\section{ADALYA}

The Annual of the Koç University Suna \& İnan Kıraç Research Center for Mediterranean Civilizations (AKMED)

Mode of publication

Adalya, a peer reviewed publication, is indexed in the A\&HCI

(Arts \& Humanities Citation Index) and CC/A\&H (Current Contents / Arts \& Humanities)

Adalya is also indexed in the Social Sciences and Humanities Database of TÜBİTAK/ULAKBIM TR index and EBSCO.

Publisher certificate number

Worldwide periodical

18318

ISSN 1301-2746

Publisher management

Koç University

Rumelifeneri Yolu, 34450 Sariyer / İstanbul

Publisher Umran Savaș İnan, President, on behalf of Koç University

Editor-in-chief Oğuz Tekin

Editors Tarkan Kahya and Arif Yacı

English copyediting Mark Wilson

Editorial Advisory Board (Members serve for a period of five years)

Prof. Dr. Mustafa Adak, Akdeniz University (2018-2022)

Prof. Dr. Engin Akyürek, Koç University (2018-2022)

Prof. Dr. Nicholas D. Cahill, University of Wisconsin-Madison (2018-2022)

Prof. Dr. Edhem Eldem, Boğaziçi University / Collège de France (2018-2022)

Prof. Dr. Mehmet Özdoğan, Emeritus, Istanbul University (2016-2020)

Prof. Dr. C. Brian Rose, University of Pennsylvania (2018-2022)

Prof. Dr. Charlotte Roueché, Emerita, King's College London (2019-2023)

Prof. Dr. Christof Schuler, DAI München (2017-2021)

Prof. Dr. R. R. R. Smith, University of Oxford (2016-2020)

(c) Koç University AKMED, 2020

Production Zero Production Ltd.

Abdullah Sok. No. 17 Taksim 34433 İstanbul

Tel: +90 (212) 2447521 • Fax: +90 (212) 2443209

info@zerobooksonline.com; www.zerobooksonline.com

Printing Fotokitap Fotoğraf Ürünleri Paz. ve Tic. Ltd. Şti.

Oruç Reis Mah. Tekstilkent B-5 Blok No: 10-AH111

Esenler - İstanbul / Turkey

Certificate number: 47448

Mailing address

Barbaros Mah. Kocatepe Sok. No. 22

Kaleiçi 07100 Antalya - TURKEY

Tel: +90 (242) 24342 74 • Fax: +90 (242) 2438013

https://akmed.ku.edu.tr

E-mail address $\quad$ adalya@ku.edu.tr 


\section{Contents}

Burçin Erdoğu

Capturing the Seen and Unseen in the Beldibi Rock Art .. 1

Özlem Çevik - Murat Dirican - Aydın Ulubey - Osman Vuruşkan

The Galena Objects from Neolithic Ulucak: The Earliest Metallic Finds in Western Turkey 7

Abdullah Hacar - K. Aslıhan Yener

Anatolian Pot Marks in the 3rd Millennium BC: Signage, Early State Formation, and

Organization of Production 25

A. Tuba Ökse

Reflection on the Sunrise Positions in Early and Middle Bronze Age Extramural

Cemeteries in Anatolia 59

Sevgül Çilingir Cesur

The Timing of Ritual Performance in Hittite Texts: The "Morning" Rites 87

Dries Daems

Reassessing the Origin of Polis in Lycia and Southwest Anatolia 111

Fatma Şahin - Erkan Alkaç

Banded Bowls from Tepebağ Höyük (Cilicia Pedias)

Özgün Kasar - Kaan İren

Leaded Bronze Arrowheads at Daskyleion 175

Hazar Kaba

An Elite Tomb from Soloi: New Evidence for the Funerary Archaeology of Cyprus

Erkan Alkaç - Ulus Tepebaş

The Gem Stamp on the Handle of a Mushroom-rimmed Amphora from Knidos:

An Assessment of the Centauromachy in Terms of Stamps and Iconography

Hüseyin Sami Öztürk - Ögül Emre Öncü

Olympos in Lycia: A Novel Assessment of its History and Localization in Light of Recent

Archaeological and Epigraphical Research

Nihal Tüner Önen

Two New Inscriptions from the Claudian Period at Perge 277

Handegül Canlı

A Unique Roman Folding Knife Handle with Eagle Ornament from Philadelphia in Cilicia 289 
Şenkal Kileci - Birol Can

A New Honorific Inscription from Blaundos: Tiberius Claudius Lucius, the Priest of

Dionysos Kathegemon

Ahmet Tolga Tek - Hacer Sancaktar

A Numismatic Riddle from Arykanda: The God of the Water Spring .

Mark Wilson

The Discovery of a Menorah in Attalia (Kaleiçi, Antalya) and its Significance for

Jewish Communities in Pamphylia

Özgü Çömezoğlu Uzbek

A North African Plate Unearthed in the Andriake Excavations

Philip Bes

Early Byzantine Pottery from Limyra's West and East Gate Excavations

Nilgün Elam

Ecclesiastical Personages of Side ( $\Sigma i \delta \eta$ ) of Pamphylia according to Literary and Sphragistic Data

Ömür Bakırer

Window Glass from the Excavations in the Seljuk Palace at Alanya

Mahmut Demir - Terrance Michael Patrick Duggan - Erkan Kurul

Observations and Assessments of Some Epigraphic Graffiti Found on Entrances in

Kaleiçi/Antalya

Ayşe Ozil

A Traveller in One's Homeland: Local Interest in Archaeology and Travel Writing in the

Ottoman Greek World in 19th Century Anatolia

Alex Rodriguez Suarez

Two Church Bells from Antalya: Traces of the Religious Soundscape of the Late Ottoman Period 517 


\title{
Leaded Bronze Arrowheads at Daskyleion
}

\author{
ÖZGÜN KASAR - KAAN IREN*
}

\begin{abstract}
Arrowheads made of leaded bronze and unearthed in Daskyleion during the excavations between 1954-1959 and 1988-2019 constitute the subject of this study. 406 leaded bronze arrowheads have been found up to now in a grave named Tumulus T6. Leaded bronze arrowheads from Daskyleion date to the 5th and 4 th centuries BC. The arrowheads are here classified according to their function. Especially some of the suggestions on archaeological typology proposed by different scholars are practically tested here as a case study using the Daskyleion arrowheads. This typology points to which arrowheads were used as military or hunting weapons in Daskyleion. It can be argued that lead, highly detected, was used in these arrows for "engineering" purposes. In addition, the deformation observed on the arrowheads is explained using historical events that occurred in the settlement and narrated by ancient authors. Consequently, the leaded bronze arrowheads used at Daskyleion are comprised of samples quite common in the Eastern Mediterranean. Fortunately, these examples were mostly found in the datable layers at Daskyleion.
\end{abstract}

Keywords: Daskyleion, tumulus, leaded bronze, weapon, arrowhead

\section{Öz}

Daskyleion'da 1954-1959 ve 1988-2019 y1llar1 arasındaki kazı çalışmalarında açığa çıkarılan kurşunlu tunçtan üretilmiş ok uçları çalışmanın konusunu oluşturmaktadır. Günümüze kadar yerleşmede ve T6 Tümülüsü olarak adlandırılan mezarda toplam 406 adet kurşunlu tunç ok ucu ele geçmiştir. Bu ok uçlarının, MÖ 5. ve 4. yüzyıl içlerinde Daskyleion'da kullanıldıkları görülmektedir. Ok uçlarının, form özellikleri değerlendirilerek ne için kullanıldıkları konusunda çıkarımlarda bulunulmuştur. Literatürdeki tipoloji önerileri burada Daskyleion ok uçlarında pratik olarak test edilmiştir. Bu tipoloji, Daskyleion'da hangi ok uçlarının askeri veya av silahı olarak kullanıldıklarını göstermiştir. Yüksek oranda saptanan kurşunun bu oklarda bir "mühendislik" amacıyla kullanılmış olduğu savlanabilir. Ayrıca, bu ok uçlarında gözlemlenen deformasyonlar 1ş1ğında, ìlk Çağ yazarları tarafından yerleşmede meydana geldiği anlatılan olaylar genel olarak irdelenmiştir. Daskyleion buluntusu ok uçların bir bölümünün Doğu Akdeniz'de oldukça yaygın örneklerden oluştukları saptanmıştır. Bunların büyük bir bölümü, Daskyleion'da tarihlenebilir tabakalarda ele geçmiştir ve böylece Daskyleion'daki tabakalara ve diğer merkezlerdeki benzerlerine göre tarihlendirilmektedirler.

Anahtar Kelimeler: Daskyleion, tümülüs, kurşunlu tunç, silah, ok ucu

\footnotetext{
* Lecturer Özgün Kasar, Muğla Sitk1 Koçman Üniversitesi, Arkeoloji ve Arkeometri Uygulama ve Araştırma Merkezi, 48000, Kötekli-Muğla. Türkiye. E-mail: ozgunkasar@mu.edu.tr ; https://orcid.org/0000-0002-7806-5221

Prof. Dr. Kaan İren, Muğla Sıtkı Koçman Üniversitesi, Arkeoloji ve Arkeometri Uygulama ve Araştırma Merkezi, 48000, Kötekli-Muğla. Türkiye. E-mail: kaaniren@posta.mu.edu.tr ; https://orcid.org/0000-0002-9053-8693

This article is produced from the PhD dissertation being prepared by Özgün Kasar under the supervision of Kaan İren. This study is supported by the Ministry of Culture and Tourism, Turkish Historical Society, Muğla Sitk1 Koçman University Coordinatorship of Scientific Research Projects (with projects number 17/128, 17/095, 17/206, 17/261 and 15/142), Turkish American Scientific Research Center, Koç University Suna \& İnan Kıraç Mediterranean Civilizations Research Center (with project number KU AKMED 2018/T.1045) and Prof. Dr. Ünsal Yalçın, Prof. Dr. Ali Arslan Kaya, and Prof. Dr. Ünal Akkemik. We thank all academics and institutions that have supported this study.
} 


\section{Introduction}

Numerous metal finds were unearthed during the excavations that have continued for years at Daskyleion. Among these, arrowheads constitute the largest group in number. This must be related to the portability and practical use of arrows at any time. Arrowheads were also used as one of the main weapons in hunting and left as votive offerings in sanctuaries and as gifts to the dead in burial places. ${ }^{1}$

Although works conducted on metal finds including arrowheads have increased in recent years, they are still inadequate. ${ }^{2}$ As publications on metal finds and especially arrowheads increase, it will also be possible to comment on local interaction. Therefore, the leaded bronze arrowheads unearthed at Daskyleion, which have been systematically excavated for many years, have been chosen as the topic of this study.

Along with developments in the production processes during the Early Iron Age, moulding techniques were put into practice through mass production. Due to this production, the endurance and functionality of the arrowhead were prioritized. The use of one form for many years without any change is well known. Therefore, the arrowheads unearthed at Daskyleion and their dating are of utmost importance. The research results obtained here will provide a source for other historical data for this and other sites.

\section{Leaded Bronze Arrowheads from Daskyleion}

435 arrowheads were uncovered at Daskyleion so far. 406 of these are leaded bronze (Type I), and 29 are made of iron (Type II) so excluded in this study. ${ }^{3}$ The analysis of these arrowheads with a portable XRF device has shown that the samples other than iron are leaded bronze. Besides, the detailed microscopic examination of these arrowheads has revealed that they were produced by a moulding technique. ${ }^{4}$

In the archaeometrical study conducted on arrowheads found in Daskyleion, it was confirmed that samples analysed in this study contain a large amount of lead (Pb). According to the analysis results, the minimum $\mathrm{Pb}$ rate in these arrowheads is $1,6 \%$, thus the rate is high in Daskyleion arrowheads.

Scott states that $\mathrm{Pb}$ is not usually formed of copper ores, and for this reason, $\mathrm{Pb}$ content represents a deliberate addition of $\mathrm{Pb} .^{5}$ Gale, Stos-Gale and Gilmore also note that copper ores are quite pure; however, they may sometimes contain small amounts of arsenic and $\mathrm{Pb}^{6} \mathrm{On}$

1 Özdemir and Işıklı 2017, 51; Akar-Tanrıver 2009, 178-86; Kasar 2018, 64, fig. 9.

2 A "Workshop of Arrowheads found in Excavations" was organized by the Izmir Nif Mountain Site Presidency on 1314 December 2016, and a common terminology was prepared for arrowheads as a consequence of this workshop. A part of the data and terminology of this workshop is used in this study.

3 The determined number of Daskyleion iron arrowheads is limited to those whose forms are preserved. Apart from these, some samples, which were possibly arrowheads, have melted and almost taken the form of a stick. It should not be forgotten that, generally, weapons and other items made of iron are not preserved well in soil as compared to others made of bronze.

4 A study is still being carried out on the material and production methods of a group of leaded bronze arrowheads from Daskyleion by Prof. Dr. Ali Arslan Kaya at the Department of Metallurgical and Materials Engineering, Metallic Materials in Muğla Sttkı Koçman University. In addition to this, content analysis of the arrowheads has been done with the portable Olympus Vanta XRF device bought for the Department of Archaeology within the Infrastructure Project of Muğla Sitkı Koçman University Scientific Research Projects. Prof. Dr. Ünsal Yalçın supports the interpretation of the studies carried out with this device.

5 Scott 2010, 90

6 Gale et al. $1985,154$. 
the other hand, the researchers in question state that ternary alloy was known by metal masters in the Bronze Age. Yet samples with up to 4 or $5 \% \mathrm{~Pb}$ that were used here might have come from an impure deposit. ${ }^{7}$ According to the analysis results of the Daskyleion samples, the average $\mathrm{Pb}$ amount in the samples is too high to come from an ore.

As the result of the archaeometrical work conducted on Sardis arrowheads, it was uncovered that a certain amount of $\mathrm{Pb}$ was used in the arrowheads. Guralnick states concerning the Sardis samples that $\mathrm{Pb}$ was used in the production of bronze to reduce the cost of copper $\mathrm{Cu}$ and tin $(\mathrm{Sn}) .{ }^{8}$ On the other hand, $\mathrm{Cu}$ melts at $1085^{\circ} \mathrm{C}$. When $\mathrm{Sn}$ and $\mathrm{Pb}$ are added to the copper alloy, the degree of melting of $\mathrm{Cu}$ decreases. ${ }^{9}$ This decrease in melting temperature facilitates easier casting. ${ }^{10}$ The fact that $\mathrm{Pb}$ made moulding easier at the commencement of mass production, and that more heads were produced from one tablet in one sitting, demonstrate that $\mathrm{Pb}$ as much as $50 \%$ was added to bronze alongside $\mathrm{Sn} .{ }^{11}$ In the archaeometrical analysis of bronze arrowheads at Acemhöyük and Gözlükule, it was found out that these arrowheads were also produced by using $\mathrm{Pb}$ in high quantity. ${ }^{12}$ According to the analysis results of arrowheads found in Daskyleion, the second highest metal after the $\mathrm{Cu}$ is $\mathrm{Pb}$; $\mathrm{Sn}$ is the third. This means that the sequencing is $\mathrm{Cu}, \mathrm{Pb}$ and $\mathrm{Sn}$. Because of this as well as the lack of arsenic in the samples from Daskyleion, we prefer to speak of directly "leaded bronze" instead of "leaded tin bronze", as is sometimes found in the literature. ${ }^{13}$

Stern states that the number of iron arrowheads found in many centres in the 5th and 4 th centuries BC is less than the bronze ones. ${ }^{14}$ He associates this with the convenience of bronze heads for moulding. He also states that the arrowhead forms produced during these centuries were not suitable for iron moulding. This should not mean that no iron arrowheads were produced between the 9th and 6th centuries BC. There are centres in which bronze and iron arrowheads have been uncovered since the Early Iron Age. ${ }^{15}$ Along with this, there are also samples, as in the example of Sardis, in which iron arrowheads were found in the same layer as copper alloy and leaded bronze. ${ }^{16}$ Moreover, as iron arrowheads are shaped by hammering metal, the retention time of their production is longer compared to those that are produced from a mould. ${ }^{17}$ For this reason, the number of bronze and leaded bronze arrowheads in scientific excavations is more in proportion to those made from iron. This quantity is also valid for Daskyleion arrowheads from the arrival of the Persians to Anatolia in the Middle Ages. Additionally, Summers suggests that leaded bronze trilobate arrowheads took the place of iron arrowheads from the mid-6th century BC onwards based on the form and dating of iron arrowheads found in Gordion and Kerkenes. ${ }^{18}$

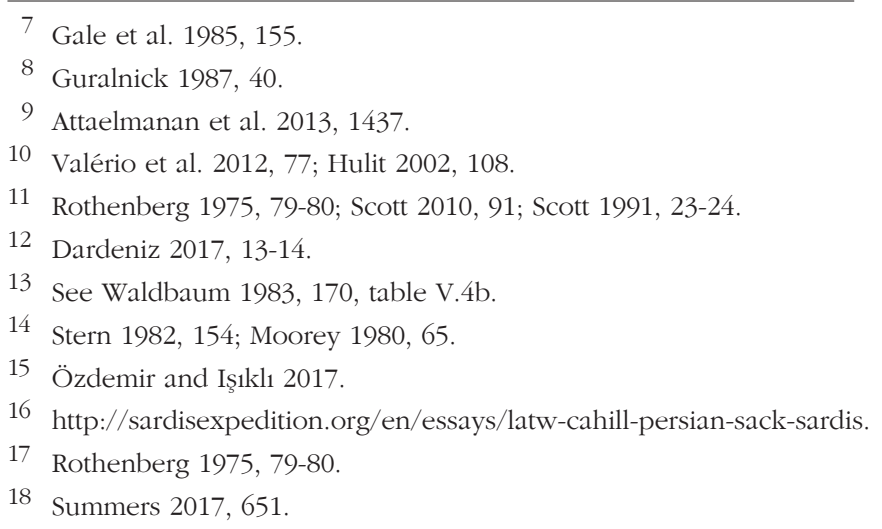




\section{The Location of Leaded Bronze Arrowheads at Daskyleion and Their Condition}

Arrowheads were uncovered in the settlement and in a grave named Tumulus T6 at Daskyleion (fig. 1). ${ }^{19}$ Tumulus T6 is located in the eastern necropolis, about $10 \mathrm{~km}$ away from AcroDaskyleion. T6 is probably a monumental family grave with multiple burials and three klines in the grave chamber.

The single place where arrowheads were brought to light en masse in Daskyleion is at Tumulus T6. A great number of leaded bronze arrowheads were among the finds in this burial area. These arrowheads number 91 - 32 being bilobate and 59 being trilobate. Wooden shaft finds are protected on the sockets of some arrowheads. ${ }^{20}$ However, since treasure hunters had robbed this grave at some point in time, these arrowheads were found dispersed under the western and southern klines and in the middle of the grave chamber (fig. 2). ${ }^{21}$

These arrows must have been left in the grave in a quiver. As a matter of fact, Minns states that there were around 300 arrows in a single quiver in Scythian graves. ${ }^{22}$ The number of arrowheads unearthed in Tumulus T6 is ideal for a single quiver or gorytos (kind of quiver and bow case). At the same time, the shape, size and weight of these arrowheads are different from each other (fig. 3). Rausing explains the existence of different forms of arrowheads in one quiver as a sign of use of arrows for different purposes with a single bow. ${ }^{23}$ A similar explanation must be valid for the arrowheads found in Tumulus T6.

A bronze ornament belonging to a gorytos, possibly made of organic material, was found in the grave chamber (fig. 4). This ornament shows that a large number of arrows was put into the burial place in a gorytos. A very similar version of this gorytos piece is seen on the gorytos on the back of Persian soldiers depicted on the Persepolis reliefs (fig. 5). ${ }^{24}$ Besides, a significant amount of the arrowheads found in Tumulus T6 consists of trilobate samples favoured by the Persians and often found on Persepolis city walls. ${ }^{25}$ Some high-quality pottery from Attica, dated to 470-420 BC, was also discovered in the grave chamber of Tumulus T6. ${ }^{26}$

Statistical data on arrowheads show that these weapons were found mostly in buildings and in their vicinity on Acro-Daskyleion (fig. 6). ${ }^{27}$ Arrowheads were specifically concentrated on the south part of the hill. The most important reason for this is that the south part of the hill was terraced and accommodated more structures depending on the topographic characteristics of the hill from the Lydian Period to the mid-Hellenistic Period. At the same time, the

19 See for T6 Tumulus, Bakir et al. 2013.

20 The anatomic analysis of two slivers $(3,4 \mathrm{gr}$ and $0,1 \mathrm{gr}$ ) of wood taken from the sockets of these arrowheads was conducted by Prof. Dr. Ünal Akkemik from the Faculty of Forestry, Istanbul University under the governance of the Bandirma Museum by permission of the Ministry of Culture and Tourism.

21 Kasar 2018, 63-64.

22 Minns 1913, 68.

23 Rausing 1967, 164.

24 Baitinger 1999, 131, figs. 6-7. In the depiction on the aforementioned relief, the arrow case used by the Persians is called a gorytos.

25 Curtis and Tallis 2005, 232, fig. 429.

26 These vases are being studied for publication by Çiçek Karaöz.

27 This map was constructed according to the number of arrowhead finds in trenches excavated up to now. There has not been an excavation in the area encircling the top of the hill and in areas represented with blue color. In other parts of the hill, the ArcGis program is preparing a colored statistical evaluation between the excavated grids whose numerical values have been given and those about which no data has been entered. The density of finds in fig. 6 was prepared by topographical engineer Hasan Şarlak on an ArcGis program. We thank Mr. Sarlak for his help. 
connection of this area to the so-called Cultic Road must have accelerated the active formation of these construction activities. Traces of this structuring have been revealed during the excavations that have continued since 2006 around the trenches in the southern part of the Cultic Road. In this area, the first phase of the bedrock pits and then the building remains of the Lydian and Persian cultures were found. ${ }^{28}$ The building and its surroundings, used first by the Lydians and later by the Persians, was named the Three Roomed Structure by the archaeological team. It is among the places where arrowheads have been most intensely found around this region until today.

Another area in which arrowheads were most intensely discovered on the Acropolis is the area called Trench F located in the northeast side of the hill. A dense formation of buildings has been observed in this area as well since the Lydian Period. With the last quarter of the 4 th century $\mathrm{BC}$, the number of arrowheads became concentrated in the area where Hellenistic Period construction is located on the south slope of Acropolis. This construction (fig. 6) and its surroundings became the place where the most arrowheads were uncovered within the area.

The preservation and the deformation of the discovered arrowheads from Daskyleion give some information about the targets of the arrows. In the examination of the pieces from this aspect, the deformations resulting from slamming on a rock or armour were observed on the blades and tip parts of $10 \%$ of the finds. The tip of an arrowhead found during cleaning of a section in front of the so-called Persian Wall was bent as a result of slamming on a hard surface (fig. 7a). Interestingly, a fish scale of an armour from Daskyleion was destroyed by a piercing weapon (fig. 7b). More distortion and deformation are observed on trilobate Type IB1a samples, which constitute the largest group among Daskyleion arrowheads, in comparison with the other samples that emerged in the same area. The deformation in these samples is usually observed in the form of bending and warping of the blades (fig. 7c). This indicates that the arrow was stuck piercing a hard surface like an armour. On the other hand, distortion and deformation of the Daskyleion bilobate samples are in the form of fracture of a part of the arrowhead and bending of the tip part (fig. 7d). Both types of deformation observed on the arrowheads are the most important proof showing arrows were used as assault weapons at Daskyleion.

\section{Typology}

Different typologies have been suggested in studies conducted on arrowheads. One of the most comprehensive studies was carried out by Smirnov and Petrenko. ${ }^{29}$ Snodgrass prepared a general arrowhead classification in his analysis on weapons. ${ }^{30}$ Hančar included an extensive typology in his publication dated 1972, in which he analysed Scythian arrowheads. ${ }^{31}$ Erdmann did a comprehensive classification work on arrowheads used in the Marathon battle. ${ }^{32}$ In his article published in 1977, Cleuziou gave a chronological typology of the arrowheads in the Near East dated between the 9th and 3rd centuries BC. ${ }^{33}$ Baitinger, in his publication of 2001,

\footnotetext{
28 İren and Yildizhan 2017, 339.

29 Smirnov and Petrenko 1963, 51, table 12.

30 Snodgrass 1964, 152, fig. 10.

31 Hančar 1972.

32 Erdmann 1973, 35, fig. 1; 45, fig. 2; 49, fig. 3.

33 Cleuziou 1977, 189, fig. 1.
} 
prepared a typology for arrowheads found in Olympia. ${ }^{34}$ In his study on weapons found in Anatolia from the 12th to the end of the 6th centuries BC, Yalçılı prepared a comprehensive typology of bronze arrowheads. ${ }^{35}$

Typology has been for a long time an arena of debate in almost every science. Unfortunately, archaeology is no different. ${ }^{36}$ A single kind of "correct" typology does not seem to exist. ${ }^{37}$ Contrarily, different approaches are acceptable for constructing typologies. The reason to construct a typology is either to answer a question of the archaeologist (basic) or to let the artefact "talk" for itself (instrumental). ${ }^{38}$ The traditional intuitive construction of typology is omitted in this article; instead, the basic proposals were accepted. In this suggestion, to build many different typologies is possible with similar material depending on the question. Although there are many questions on arrowheads, such as when, where, by whom, etc., we decided to test their functions in praxis using the suggestion of Adams and Adams. So the arrowheads of Daskyleion are a case study towards this purpose.

Every instrument, inclusive of arrowheads, could have a multipurpose use, but every instrument also has a "native one". The assumed native purpose of the arrowhead is primary for the typology here. 39

While creating the Daskyleion arrowhead typology, all arrowheads were split into two groups according to their compositional differentiation: leaded bronze (Type I) and iron (Type II). Leaded bronze ones are also divided into two according to their primary function. These functional types of the arrowheads are hunting arrowheads (A) and warfare arrowheads (B). ${ }^{40}$ Every type is itself divided into two. The first type consists of arrowheads that pierce hard surfaces (1), while the second is made up of arrowheads that hit or pierce the skin directly with an aim to kill (2). Subdivisions of these classifications are morphological and arranged chronologically (figs. 8-9).

As one may obviously notice, the typology constructed here is a hybrid classification that does not ignore morphology and composition, although it is mainly based on the functionality of the arrowheads.

The invention of the arrow must go back to husbandry times in the Palaeolithic Period. ${ }^{41}$ The arrow brought to humans the facility to hunt the animals from a distance. Surely, it could be used later in wars between early clans.

However, the main concept of war was triggered by the transition to a sedentary lifestyle with the concept of property and the instinct to protect $\mathrm{it}^{42}$. The bow and arrow became the most commonly used weapon in war. ${ }^{43}$

\footnotetext{
34 Baitinger 2001.

35 Yalçıklı 2006, 282, table 6; 2016, 460, table 8.

36 Adams 2008, 1026.

37 Adams 2008, 1027.

38 Adams and Adams 1991, 157-68.

39 There is no single objective version of human affairs; see Trigger 2006, 447.

40 This presumes that hunting arrowheads started earlier than warfare ones.

41 Rudgley 2000, 165.

42 Otto et al. 2006, 41-42.

43 Otto et al. 2006, 361 .
} 
The piercing or destructive force of arrowheads depends firstly on speed, weight and form. For example, if the arrowhead is heavy, it cannot go far, but its impact is greater than with lighter types. ${ }^{44}$

While features such as form, weight, and wing number are defined in arrowhead production, calculations are also made as to what purpose the arrowhead will serve. For large game, for example, the hunter would need a wide arrowhead with a cutting edge along with a compatible bow. If the archer shoots the arrow on horseback, the bow needs to be short and the arrowhead smaller. Since there is a close relationship between the arrowhead's function and its features, the characteristics of both arrowhead forms are described here in general terms. A drawing showing the parts of an arrowhead is given to make more understandable the terminology used here (fig. 10).

Additionally, in a table of the typology of Daskyleion arrowheads, the XRF analysis results for each type of arrowhead have been provided in terms of compositional range. Also, the number of each kind of arrowhead uncovered up until today is noted in the same figure.

\section{IA. Hunting Arrowheads}

Animals commonly hunted in ancient times were deer, roebuck, boar and fox. Also hunted were bird species such as pheasant, partridge, quail, starling, duck, and small animals such as hares and hedgehogs. ${ }^{45}$

Daskyleion arrowheads were used not only for combat but also for hunting. According to the ancient sources, there was a significant Persian hunting park (paradeisos) at Daskyleion. ${ }^{46}$ Preliminary zooarchaeological studies on animal bones report the uncovering in Daskyleion of the bones of different varieties of deer and hare along with unidentified bird species. ${ }^{47}$ It is known from bullae found in the first years of the Daskyleion excavations that various species of birds lived in this area in ancient times just as they do today. ${ }^{48}$ Evliya Çelebi's travel book contains some information on Bird Lake:

The origin of its name is the fact that the lake's water comes from the İlyas spring on the ---- side. The Turkmens call it Lake Manyas, which is a corrupt form of "ma-i İlyas" "water of İlyas". Its circumference is ---- leagues, but it is not a deep lake. It is a "water of İlyas", which indeed resembles the "elixir of life". One catches trout, pike, eels, ----, and all other sorts of exquisite fish in it. Designated fishermen submit these fish as tax-not everyone is allowed to fish here for personal pleasure or livelihood. In wintertime, this lake brims with geese, ducks, ruddy shelducks, swans, cormorants, fieldfares, red ducks, mallards, seagulls, goldfinch, and many hundreds of colours of wild birds, and the plain of Manyas trembles every night with the sound of swans, geese and ruddy shelducks and the beating of their wings. The hunters of these birds too pay them as tax at a fixed lump sum rate. ${ }^{49}$

\footnotetext{
44 Ureche 2013, 187.

45 Alcock 2006, 69-75; Soyer 2004, 182-200.

46 Xen., Hell. 4.1.15-16.

47 There is an unpublished "preliminary report" on the zooarchaeological finds at Daskyleion by İ. Özer, İ. Gürgör, S. İlbey (Daskyleion Archive)

48 Bakir 2011, 58.

49 Evliya Çelebi, Seyahatname V.88b.16 (513).
} 
Today Manyas Lake is rich in plankton content and host to 266 species of birds. Other species such as boar, fox, hedgehog and mole continue to live in the region. ${ }^{50}$

From what can be determined, two different types of arrowhead forms were used to kill various types of animals in Daskyleion. These were arrows with wide cutting edges and small pyramidal arrowheads. These types of arrowheads varied depending on the size and activities of the animal hunted. For example, if the game was partridge, marsh hens, or quail of the pheasant family, the need would be for a lightweight and small arrowhead that would speedily hit the target.

\section{Type IA1}

The arrowheads in this group have wide cutting edges, and for this reason have a high capacity for damage. ${ }^{51}$ The reason behind this is to cause a deep laceration in the skin and a fast outflow of blood so that the animal can be caught without escaping too far. ${ }^{52}$ More than one arrow piercing a large wild animal will increase blood loss and bring the animal to the ground. Sometimes, as seen in Assyrian reliefs, strong animals such as lions are brought down by numerous arrows that will deplete the animal's strength, after which the killing blow is dealt by a spear or sword..$^{53}$ It is possible that the type of wide arrowheads with cutting edges found in Daskyleion was used in hunting large wild animals.

Type IA1a is among the bilobate arrowheads. 19 arrowheads were uncovered in total - 16 from Tumulus T6, the other 3 from the Acropolis. In this group of samples, the midrib is conical while the body is diamond-shaped. They are approximately $3 \mathrm{~cm}$ long. Their weight ranges from 1,74 to 3,13 gr. Only one sample is prominently bigger. Their sample height is $5 \mathrm{~cm}$ on average. Their width between the two blades ${ }^{54}$ is $1,8 \mathrm{~cm}$, and their weight averages $7 \mathrm{gr}$.

In this group, the defining characteristic is that the socket is hidden in the body, and the surface between the two blades is wide. Malloy states that wide-bladed arrowheads have a skin-piercing feature, and samples with a narrow blade surface are ideal for piercing shields, leather and clothing. ${ }^{55}$ Rausing mentions that arrowheads with wide-surfaced blades put up more resistance in the air in comparison with samples with narrow blades. ${ }^{56}$ The relatively big and heavier arrows are advantageous to cause fatal wounds, but their flight distance is lesser than lighter ones and vice versa.

Similar samples in this group were unearthed in layers related to the Persians on the Athenian Acropolis. ${ }^{57}$ A similar sample of this type was unearthed in Lindos and dated to $490 \mathrm{BC}$ by the researcher. ${ }^{58}$ Another similar sample was uncovered in Kamiros and dated to the 6th and 5th centuries BC. ${ }^{59}$ Similar versions of this type must have been used at Daskyleion around the 5th century BC.

\footnotetext{
50 Sözüer 2018, 593.

51 Forsom and Smith 2017, 281; Delrue 2007, 246; Blackmore 2000, 148; Paterson 1984, 33.

52 Gilbert 2004, 27.

53 Frankfort 1970, 99, pl. 109.

54 We refer here to the widest part of the body, that is, from one edge of a blade to the other.

55 Malloy 1993, 5.

56 Rausing 1967, 163.

57 Broneer 1935, 114-15, fig. 4; Broneer 1933, 342, fig. 13e-f.

58 Blinkenberg 1931, 195, table 23, fig. 601.

59 Bernardini 2006, 62, table 13, no. 53.
} 


\section{Type IA2}

The examples in this group are lightweight, small arrowheads that can travel long distances if needed. Their capacity to injure by piercing and inducing loss of blood is negligible compared to other examples of arrowheads. These arrowheads are used to kill a target by yielding a hard blow and stunning the animal. This type of arrowheads must have been used in Daskyleion particularly for hunting hare and small-sized birds such as partridge, marsh hens and quail. Moreover, this type of arrowheads, used to hit and kill, also allowed the animal's skin and hide to remain undamaged. ${ }^{60}$

Type IA2a is another important group among Daskyleion trilobate arrowheads. The body of the samples of this type is thin, long and triangular. They range from 2 to $3,5 \mathrm{~cm}$ in height. The width between blades ranges from 0,6 to $1 \mathrm{~cm}$. A typical characteristic of this type is that the blades point towards the socket like a barb.

There have been 12 samples of this type discovered in Daskyleion. 2/3 of these samples were found in Trench M-8 opened on the south slope of the Acropolis. In this trench, the foundations of a tower called Structure A were found, with ground walls measuring $1,20 \mathrm{~m}$ revealed during Akurgal's excavations. A burnt layer $50 \mathrm{~cm}$ thick was found under the main blocks of this tower, and in situ vases were found right upon this burn layer. This fire was noted on many parts of the Acropolis and could be dated to Agesilaos' destruction. The pottery sherds found in this layer are dated to the early 4th century BC. ${ }^{61}$ Because of this circumstance, the construction of the tower should be dated later than 395 BC. The arrowheads found in this area should also be dated later depending on the context. A similar sample of this type uncovered in the 2011 excavations on Grids G-XXXII/XXXIII and H-XXII/XXIII on the west slope of the Acropolis was found on Floor Number 2 dated to the early 4th century BC. ${ }^{62}$ Another sample, unearthed in 2006 in a trench named Archive Building-North, is from a deposit dated to the 4th century BC. ${ }^{63}$

Type IA2b is pyramidal, small and light in comparison with the other arrowheads. Their height is between 2,2 and $3,2 \mathrm{~cm}$; their width is $0,8 \mathrm{~cm}$ on average. Their weight ranges from 1,55 to 1,77 gr. Six of the IA2b type were unearthed in layers dated to the 4 th century BC in the settlement. This type was also found during excavations in Heraion Teichos and dated to the same century. ${ }^{64}$

Erdmann assesses samples of this type within group CIIc8 in his classification. ${ }^{65}$ Robinson examines similar samples of this type in Type GIII among the Olynthos arrowheads. Robinson argues that Northern Greece and the Balkans were mainly responsible for the distribution of this type in the period later than the 5th century BC. He also states that similar samples uncovered in Olynthos were found in the Thracian or Macedonian destruction layer dated to 348 BC. ${ }^{66}$ Olson and Najbjerg analyse arrowheads found in Cyprus that were similar to the Daskyleion sample and include these samples among Type BII, stating that these arrowheads

\footnotetext{
60 Sawyer and Sawyer 2011, ch. 19.

61 Bakir et al. 2003, 491.

62 The diary reports of the Trench Grids G-XXXII/XXXIII and H-XXII/XXIII, 2011, 14.

63 The diary reports of the Trench Archive Building-North, 2006, 12.

64 Atik 2017, 73, fig. 5.

65 Erdmann 1973, 47, fig. 2.

66 Robinson 1941, 405.
} 
were developed in the 5th century BC. ${ }^{67}$ Daskyleion IA2b samples need to be dated to the 4th century BC according to comparable arrowheads and the layer in which they were found in the settlement.

Two samples of Type IA2c were brought to light in Daskyleion. This type of arrowheads is pyramidal and small. Their height is 2,3 and $2,8 \mathrm{~cm}$, and their body width is 0,8 and $1,1 \mathrm{~cm}$. Their weight is 2,46 and 3,37 gr. Erdmann includes similar samples of this type in CIIc10. ${ }^{68}$ Due to the deposits in which these arrowheads were found, it can be argued that this type was used in Daskyleion during the 4th century BC.

Daskyleion Type IA2d is represented with two samples, which are also pyramidal. Their heights range from 2,3 to $2,4 \mathrm{~cm}$. Their body widths range from 0,6 to $0,7 \mathrm{~cm}$, and their weights range between 1,60 and 1,71 gr.

A similar sample of this type was found in the destruction layer dated to 480-479 BC and located on the west side of Building $\mathrm{H}$ in Athens. This type also bears a resemblance to the material unearthed in the Persian layers on the north slopes of the Acropolis. ${ }^{69}$ A similar sample of this type in Cyprus was found in the Persian layer. ${ }^{70}$ Olson and Najbjerg also consider arrowheads found in the Polis Khrysochous settlement in Cyprus that are similar to Daskyleion Type IA2d. These also date to the 5th century BC. ${ }^{71}$ Erdmann places similar samples of this type in the CIIc2 group in his classification. ${ }^{72}$ Deposits in which this type were uncovered in Daskyleion are dated between the late 5th and late 4th centuries BC.

\section{IB. Warfare Arrowheads}

Arrows are used in different types of bows by infantry and mounted archers during war. ${ }^{73}$ The arrowheads that may have been used in war are divided into two subtypes - those with skinpiercing properties and those with armour-piercing properties.

\section{Type IB1}

The arrowheads in this group are trilobate and have the capacity to pierce armour. The reason trilobate arrowheads were used against armour was that this type is more resistant to bending compared to other arrowheads. ${ }^{74}$ The greater the capacity of an arrowhead to pierce armor, the more its chance of being used in war. ${ }^{75}$

Type IB1a is one of the most frequent groups among trilobate arrowheads. These samples were found both in the settlement and in the grave chamber of the tumulus. ${ }^{76}$ One of the main features of this group is that the socket is hidden in the body. The midrib is straight. The body of these arrowheads is diamond-shaped. The shortest one is $2,4 \mathrm{~cm}$ long while the longest is $3,8 \mathrm{~cm}$. The most commonly used height value in this type is $3,1 / 3,2 \mathrm{~cm}$. The body widths range from 1,1 to $1,2 \mathrm{~cm}$, and their weights range from 2,80 to $4,59 \mathrm{gr}$.

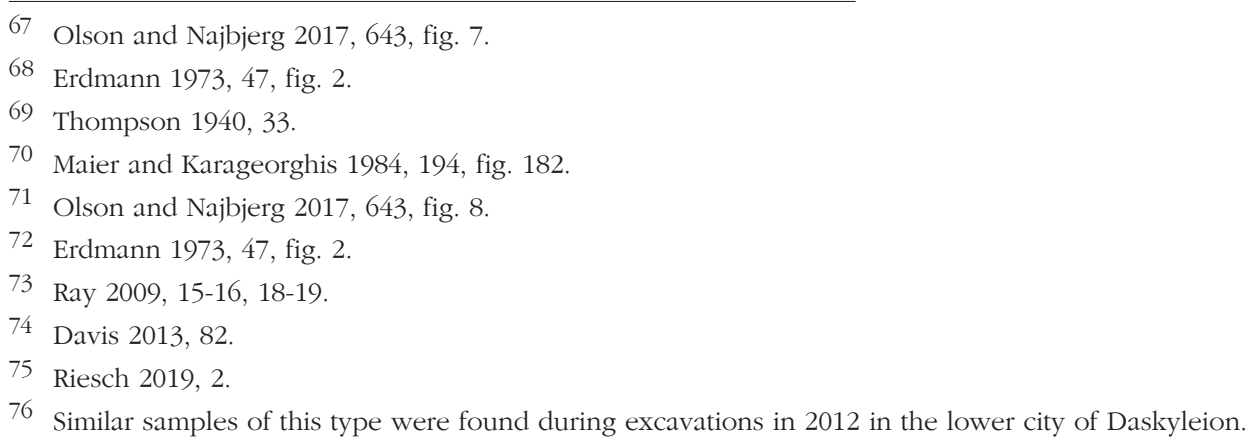


Rausing considered that arrowheads with sockets were first brought to Anatolia by Scythians via the Caucasus. ${ }^{77}$ A relationship was also mentioned between the Scythians and some arrowhead types uncovered in large amounts in Persepolis, ${ }^{78}$ among which there are some types also found in Daskyleion (Types IB1a and IB1b). Erzen stressed that these arrowhead types were used by the Scythians who surrounded Çavusstepe. ${ }^{79}$ Considering the relationship between Urartu, Assyria and Media, it is suggested that this type of arrowheads was later copied by the Persians. ${ }^{80}$ Indeed, a large number of this type were found in Persepolis, causing this form to be relabelled as "Persian". It is possible to suggest that this type of arrowheads was developed in Persian territories; however, they spread to all Mediterranean lands and were widely used by various peoples.

Guralnick called this type of arrowheads found in Sardis as "Persian". ${ }^{81}$ Similarly, Hellmuth uses the name "Persian type" for arrowheads similar to Daskyleion type IB1a and IB1b. ${ }^{82}$ With the expansion of the Persians into Anatolia and the Mediterranean region, these arrowhead types later appeared within a larger geographical distribution. The fact that this type of arrowheads was uncovered in large amounts in centres like Smyrna, Sardis, Gordion and Cyprus - where destruction by the Persians occurred - increased the identification of these arrowheads with the Persians. Although all the arrowheads in these aforementioned types were found in the Persian destruction layers due to the siege of Sardis, Greenewalt pointed out that it is impossible to attribute them to one of the parties in the battle. ${ }^{83}$ Indeed, it is not plausible to assign cultural and/or ethnic ownership concerning arrowheads.

Samples comparable to Daskyleion Type IB1a emerged in a number of centres in the Near East and Mediterranean region. Curtis and Tallis mention that these arrowheads are small and light, and for this reason, they could be effectively used by mounted archers. Also the same arrowheads could be produced easily and quickly. ${ }^{84}$ The fact that this form spread to a wide area could be related to these reasons. Similar samples of this type were also discovered among a group of metal artefacts preserved in the private collection of Ahmet Köroğlu. ${ }^{85}$ They are considered as finds from a grave. The artefacts in this collection are dated to the final period of Urartu during the reign of King Rusa (773-653 BC).$^{86}$ The arrowheads in this find group are similar to Daskyleion Type IB1a samples and show that this form was produced starting from the second quarter of the 7th century BC.

Sardis is another centre in which this type was found. Recent samples uncovered there were found in a garbage pit found during the 2018 excavations and dated to the 5th century BC. ${ }^{87}$ Also, more than 150 bronze arrowheads were found at the Palai Paphos settlement in

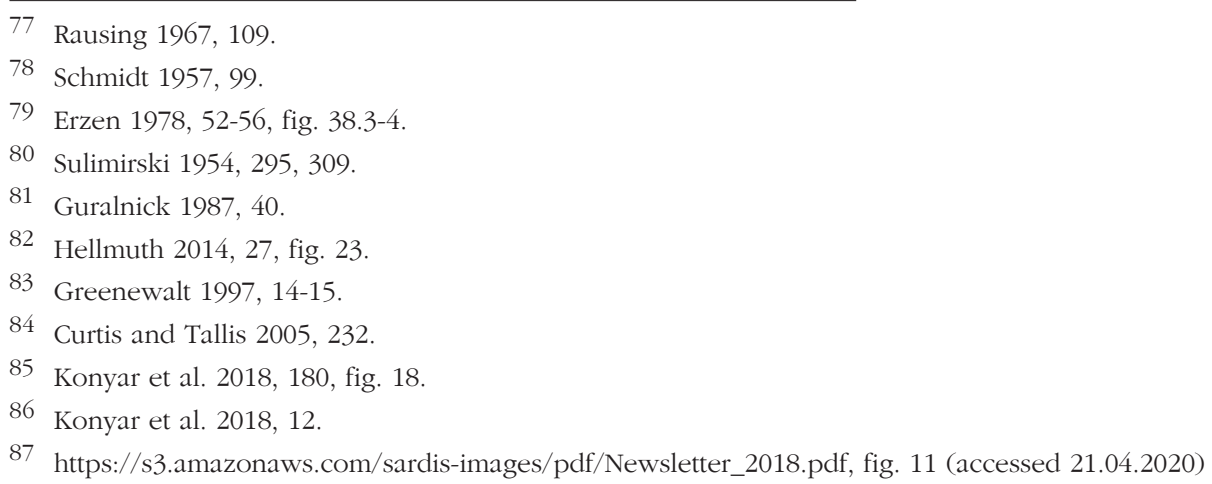


Cyprus. Most of these have sockets and are trilobate. Among the samples are arrowheads similar to Daskyleion IB1a. ${ }^{88}$ These samples in Cyprus were discovered in a Persian destruction layer dated to the 5th century BC. Among the places in which similar samples of this type were found include Metropolis, ${ }^{89}$ Klaros, ${ }^{90}$ Alişar Höyük, ${ }^{91}$ Kerkenes, ${ }^{92}$ Kelainai-Apameia, ${ }^{93}$ Kaman Kalehöyük, ${ }^{94}$ Deve Höyük, ${ }^{95}$ Athens Acropolis, ${ }^{96}$ Corinth,${ }^{97}$ Lindos, ${ }^{98}$ Thasos Artemision, ${ }^{99}$ Pasargadai, ${ }^{100}$ Samaria ${ }^{101}$ and Daphnai. ${ }^{102}$

Explorations carried out in the Cultic Road give important information about the date in which this type of arrowheads was used in Daskyleion. In 2006, these were discovered in the trench called Cultic Road-South on the partly burnt areas of Floor I. During the removal of the floor two arrowheads were found. Archaeologists working in the trench considered this floor as a continuation of the destruction layer (395 BC) of the Spartan king Agesilaos in the trenches around the Cultic Road. That the pottery found on the floor is dated to the first quarter of the 4th century BC points to the same period for the arrowheads unearthed here. ${ }^{103}$ On the other hand, another area in which this group was found in Daskyleion was at Tumulus T6. According to the pottery discovered in this tumulus, the arrowheads do not date earlier than 420 BC.

Daskyleion trilobate Type IB1a was found together with Type IB2a as one of the bilobates in Tumulus T6. The common aspect of both these types of arrowheads is that they were found often in the same geographical area. As bilobate Type IB2a arrowheads, these samples also spread to Greece and the Near East. ${ }^{104}$ Also, these samples were discovered in layers associated with the Persians, as was the case with IB1a samples. The period in which these arrowheads were used at Daskyleion is suggested as $470-300$ BC, based on the other archaeological finds on the site.

Type IB1b is another group frequently found both in the settlement and in the tumulus. ${ }^{105}$ The midrib is straight. The blades of these arrowheads are trilobate; their body is oval. The height of these arrowheads is around $4 \mathrm{~cm}$, and the width between the blades is between 0,9 and 1,2 cm. Their weights range from 2,13 to 7,63 gr. These arrowheads are similar to Type

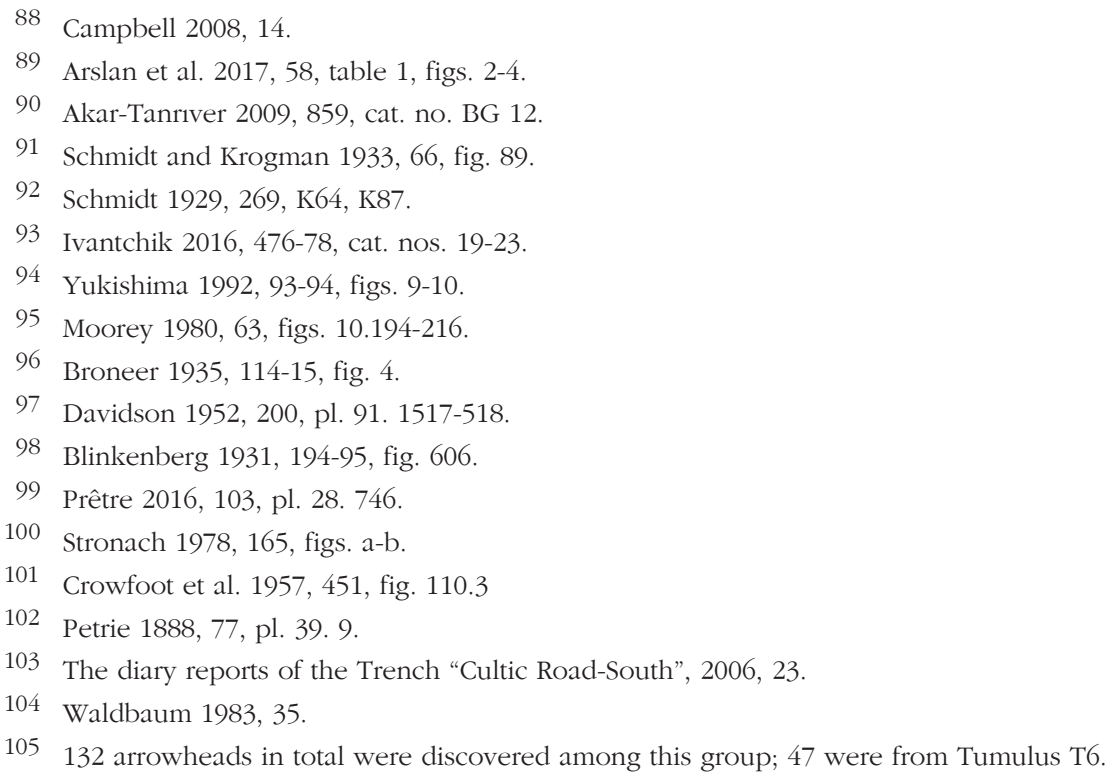


IB1a in terms of form. The main differences are that the body is longer in Type IB1b and, accordingly, the width of the blades is smaller. ${ }^{106}$

Like Type IB1b, Type IB1a was frequently found in deposits of the Middle Achaemenid Period (477-389 BC) in Daskyleion where building activity was intense around the Cultic Road and the trenches on the south. The discovery of this type of arrowheads in Tumulus T6 together with Type IB1b demonstrates that they were contemporaneous. Types IB1a and IB1b were also found together in other centres like Daskyleion. ${ }^{107}$

Type IB1c is a variation of this type wherein the height of Type IB1b is increased. In these examples, the height of the arrowhead is between 4,8 and $5,3 \mathrm{~cm}$. The widths of their body range from 0,6 to $0,8 \mathrm{~cm}$; their weights range from 3,46 to 4,41 gr. As observed in samples found in other centres and Daskyleion, this variation was used contemporaneously with Daskyleion Type IB1a. ${ }^{108}$ A similar sample of these arrowheads was found in Lindos and dated to 490 BC. ${ }^{109}$ A similar version was uncovered in Olympia, ${ }^{110}$ Nemea $^{111}$ and Tanis. ${ }^{112}$

Type IB1d has a straight midrib. The blades of these arrowheads are trilobate. The body is triangular-shaped. Their height is between 3,5 and $4,7 \mathrm{~cm}$, and the width is between 0,8 and $1,1 \mathrm{~cm}$. Their weights range from 3,82 to 5,42 gr. This arrowhead type was unearthed in the same layer as Daskyleion Type IA2b. This type was also uncovered in other layers dated to the 4 th century BC of the settlement. Therefore, this type was used in Daskyleion between the second half of the 5th century BC and the mid-4th century BC.

Type IB1e is among the trilobate arrowhead. A single sample in this type was unearthed at Daskyleion. Half of this sample consists of blades while the other half is socket. Its height is $3,4 \mathrm{~cm}$, width is $0,7 \mathrm{~cm}$, and weight is $3,20 \mathrm{gr}$.

\section{Type IB2}

Arrowheads in this group struck directly on the skin and caused intense blood loss. Among these are examples spurred or barbed. In such cases, it is difficult to remove the arrow from the skin because the wound opens further. More blood loss then occurs that could cause death while trying to remove the arrow. ${ }^{113}$

Type IB2a was one of the bilobate Daskyleion arrowheads discovered both in the settlement and in Tumulus T6. Additionally, this type is the most frequent group found among the bilobate Daskyleion arrowheads. ${ }^{114}$ The socket is long in samples of this group. ${ }^{115}$ The midrib is conical, and the body oval-shaped. The heights of Type IB2a samples range from 3,3 to

\footnotetext{
106 Among the samples of this type are arrowheads in which the width between the two blades reduces to $0,7 \mathrm{~cm}$.

107 For the Lindos samples, see Blinkenberg 1931, 606-8; Ivantchik 2016, cat. nos. 10-18; Crowfoot et al. 1957, 451, fig. 110.3, 5. For the Nemean sample, see Miller 1975, 154, pl. 37b.

108 Blinkenberg 1931, 195, table 23, fig. 608.

109 Blinkenberg 1931, 195, table 23, fig. 608

110 Curtius and Adler 1890, 178, pl. 64.1083.

111 Miller 1975, 154, pl. 37b.

112 Petrie 1888, 77, pl. 39.12.

113 Davis 2013, 79; Delrue 2007, 246.

11443 samples of this type have been discovered both in the settlement and in the tumulus.

115 There is a sample whose socket depth reaches up to $1,9 \mathrm{~cm}$.
} 
$3,8 \mathrm{~cm}$. Their weights range from 2,45 to $5,70 \mathrm{gr}$. The width of the blade's midrib is around $1 \mathrm{~cm}$. The height of a sample is $4,4 \mathrm{~cm}$. In some samples, the rivet hole is preserved.

Arrowheads of this type were discovered during the excavations at Sardis. ${ }^{116}$ It is one of the most common types among arrowheads. Waldbaum states that these samples were commonly used in the Eastern Mediterranean and the Near East from the 8th to the 4th centuries BC. She argues that this type found in Anatolian and Greek cities is a Lydo-Persian one and related with the Persian conquests. ${ }^{117}$ The date proposed in Sardis for these arrowheads is $547 \mathrm{BC}$ when Kyros was ravaging the palace. ${ }^{118}$ Metropolis is another centre in which this type was found. ${ }^{119}$ Other places where similar variations of this type have been observed are Troia, ${ }^{120}$ Didyma, ${ }^{121}$ Afyon Çavdarlı Höyük, ${ }^{122}$ Kaman Kalehöyük, ${ }^{123}$ Boğazköy, ${ }^{124}$ Kerkenes, ${ }^{125}$ Çavuştepe ${ }^{126}$ and Olympia. ${ }^{127}$

This type of arrowheads, uncovered mainly in and around the Cultic Road in Daskyleion, is dated to the early 5 th century BC based on the pottery found in the deposit. ${ }^{128}$ Samples of this type were also found in Tumulus T6. This grave is dated between 470 and 420 BC according to vases found together with the arrowheads. After the samples of this arrowhead were discovered in the tumulus, no other similar sample was found in any dated deposit in any part of the site. This arrowhead type was probably used at Daskyleion during the 5th century BC. Earlier examples did not emerge at Daskyleion so far, although they are known from other settlements. ${ }^{129}$

20 bilobate Type IB2b arrowheads were found at Daskyleion. A typical form characteristic of this type is its large-surface blades and short socket. The midrib is spindle-shaped. The midrib narrows from the socket to the middle of the midrib and ends fusiform from the middle of the midrib onwards. The body is leaf-shaped. The blades of these arrowheads are bilobate. Their height ranges from 3,8 to 4,9 cm; their weight ranges from 3,59 to 6,87 gr. The calibres of the sockets average $0,7 \mathrm{~cm}$.

\footnotetext{
116 Cahill 2015, 420, fig. 6.

117 Waldbaum 1983, 32. For the Sardis finds in 2013, see Cahill 2015, 415, fig. 6; cf. Hanfmann and Detweiler 1961, 4, fig. 4. Even though Daskyleian types IA1b and IA2c commonly found in Sardis are dated between the 6 and 4th centuries BC in Sardis, there is no data concerning the use of these samples in Daskyleion in the 6th century BC.

118 Cahill 2010, fig. 3.

119 Arslan et al. 2017, 58, table 1, fig. 1.

120 Schliemann 1884,247 , no. 132.

121 Lubos 2009, 406, table 1.7.

122 Akok 1965, 10, fig. 51.

123 Yukishima 1992, 90, 93, figs. 2.1, 4.

124 Boehmer 1972, 109-10, table 30.888, 895A.

125 Schmidt 1929, 248, 270, fig. 69 K73, K33.

126 Erzen 1978, 52-56, fig. 38.4.

127 Baitinger 2001, 109, pl. 6, figs. 152-54.

128 The diary reports of Trench "Cultic Road-South", 2005, 6.

129 Young 1953, 164-65, fig. 10, mentions similar samples found in and outside of a complex in Gordion and dated to mid-6th century BC; cf. Cleuziou 1977, 191, fig. 1, type E8; Hančar 1972, 4-6, table 1, II.4; Smirnov and Petrenko 1963, 51, table 12. 4-6; Yalçılı 2016, 132, table 8, types IIb2a1, IIb2a2.
} 
Several variations similar to this type emerge very often in the literature. Among the places where comparable samples were found are Troia, ${ }^{130}$ Larisa, ${ }^{131}$ Old Smyrna, ${ }^{132}$ Karamattepe and Ballıcaoluk, ${ }^{133}$ Sardis, ${ }^{134}$ Phokaia, ${ }^{135}$ Alişar Höyük, ${ }^{136}$ Gordion ${ }^{137}$ and Boğazköy. ${ }^{138}$

Yalçıklı proposed a circulation time of this type between the late 7 th and late 4th centuries $\mathrm{BC}$ based on the dates of the finds from other centers. ${ }^{139}$

In the case of Daskyleion among the samples of Type IB2b, there is only one which could be definitely dated. Its deposit has the pottery dated to the first half of the 5 th century. ${ }^{140}$ According to the deposits of similar samples, this type would have been used during the 5 th century BC in Daskyleion.

Three samples of Type IB2c were uncovered in Acro-Daskyleion. The midrib is conical. The blades of these arrowheads are bilobate. A characteristic feature of this type is that the blades are barbed. The body is oval-shaped. The height is $4 \mathrm{~cm}$; the width between the two blades is $1,2 \mathrm{~cm}$. Their weight ranges from 2,79 to 5,16 gr. One of these arrowheads was found in Tumulus T6. Therefore, the arrowheads in this group were used in Daskyleion in the 5 th century BC.

17 bilobate Type IB2d arrowheads were uncovered at Daskyleion. The common and most distinctive characteristic of these samples is that the socket is long and the midrib ends by narrowing from the socket to the tip. The blade of these arrowheads is bilobate. The body is triangular-shaped. The longest sample among this type is $4,4 \mathrm{~cm}$ long, while the shortest is $3,4 \mathrm{~cm}$. The width between the two blades is between 1 to $1,5 \mathrm{~cm}$. Their weight ranges from 3,34 to 6,05 gr.

The arrowhead discovered in the Gerar settlement in Palestine and dated to the 9th century $\mathrm{BC}$ is among the earliest samples similar to Type IB2d. ${ }^{141}$ Later, similar samples dated to the 7th-6th centuries BC were found in Daphnai. ${ }^{142}$ In studies conducted by Woolley in Al Mina, a similar sample of this type was discovered and dated to 650-550 BC. ${ }^{143}$

The earliest samples of this type in Greece were found in Olympia ${ }^{144}$ and Sparta. ${ }^{145}$ The date of these arrowheads varies from the 7 th to the 5th centuries BC. Comparable variations

\footnotetext{
130 Dörpfeld 1902, 419, fig. 449.

131 Boehlau and Schefold 1942, 50, tables 10.4, 10.36.

132 Akurgal 1983, pl. N3.

133 Baykan 2017a, 29, fig. 13.

134 A similar arrowhead with Type AII was observed because of the examination carried out on the Sardis database in 2019 with the permission of Nicholas Cahill. We would like to express our gratitude to Prof. Cahill for this permission.

135 Özyiğit 1994, 105, fig. 32.

136 Schmidt and Krogman 1933, 66, fig. 89. A380.

137 Young 1953, 164-65, fig. 10.

138 Boehmer 1972, 109-10, table 30.896.

139 Yalçıklı 2016, 122.

140 Coşkun 2005, 240, III. Acb1: type I, cat. no: s 366.

141 Petrie 1928, 15, pl. 29.8

142 Petrie 1888, 77, table 39.16.

143 Woolley 1938, 147, A3.

144 Baitinger 2001.

145 Dawkins 1929, 201, table 87h.
} 
of this type were discovered in many centres in Anatolia as well. The main ones are Sardis, ${ }^{146}$ Ephesos Artemision, ${ }^{147}$ Gordion, ${ }^{148}$ Kerkenes Mountain ${ }^{149}$ and Tarsus Gözlükule. ${ }^{150}$ This type unearthed in these sites are dated between the 6th and 4th centuries BC, depending on the deposits in which they were found. These arrowheads were found in several trenches on Acro-Daskyleion. Among them, five arrowheads could be dated between 440 and 310/300 BC, according to the deposits to which they belonged.

Samples in Type IB2e are spurred, and two of them were uncovered in Daskyleion. The midrib is straight; the body is oval. Their height is between 3,6 and $3,8 \mathrm{~cm}$, and the width of both is $1 \mathrm{~cm}$. Their weight ranges from 3,60 and 3,75 gr. A similar version of this arrowhead uncovered in Didyma is dated to the 7th-6th centuries BC. ${ }^{151}$ Arrowheads with similar barbs as the Daskyleion sample were found in Didyma in the burnt layer related to the Persians and dated to 494 BC. ${ }^{152}$ Unfortunately, samples of this type could not be found in dateable deposits in Daskyleion. Based on the fact that samples in other centres similar to this type are dated to the 7th and 5th centuries BC, comparable dates could be suggested for the two samples in Daskyleion from this group.

A single sample of Type IB2f was discovered at Daskyleion. The midrib is spindle-shaped. The blades are wide, and the midrib is narrow. The body is close to a leaf-shaped. The height is $4,9 \mathrm{~cm}$; its width is $1,4 \mathrm{~cm}$; and its weight is 3,95 gr. This arrowhead was found during the excavations in 2002 close to the Persian Wall. Comparable samples of this arrowhead were found in Pergamon, ${ }^{153}$ Sardis ${ }^{154}$ and Olynthos. ${ }^{155}$ The height of similar samples ranges from $4,7 \mathrm{~cm}$ to $5 \mathrm{~cm}$. However, the socket of the Daskyleion sample is longer than similar ones. Robinson states that this type of arrowhead form is similar to a spearhead. It was popular in the 5th century $\mathrm{BC}$, and the circulation time of the Olynthos samples continued until the late 4th century BC. ${ }^{156}$ A similar sample from Klaros was uncovered together with two Ephesos coins that are dated to the late 4th century BC. ${ }^{157}$ When similar samples in the literature are considered, the dating of Daskyleion Type IB2f should be in the second half of the 4th century BC. Archaeological finds confirm this date in Daskyleion as well.

Type IB2g, the defining characteristic is that the socket is shallow. The midrib is conical. The blades of these arrowheads are bilobate; their body is triangular. The arrowheads are $4 \mathrm{~cm}$ long on average, and $1,3 \mathrm{~cm}$ in width. They weigh from 3,22 to 5,75 gr. The most important difference between this type and Daskyleion bilobate Type IB2g is that the midrib is not high and the socket is shallow. In Type IB2g samples, the socket depth reaches up to $1,4 \mathrm{~cm}$. Similar arrowheads with Daskyleion Type IB2g were observed in the town of Midas. ${ }^{158}$

\footnotetext{
146 Greenewalt 1997, 3, 7, fig. 5.

147 Klebinder-Gauss 2007, cat. nos. 890-91.

148 Young 1953, 164-65, fig. 10.

149 Woolley 1938, 147, fig. 25 A.

150 Goldman 1963, 373-74, fig. 174.29.

151 Lubos 2009, table 1, fig. 9b.

152 Bumke and Röver 2002, 95-97, fig. 15.

153 Conze 1913, 252, fig. 8b.

154 Waldbaum 1983, 35, pl. 58.1001.

155 Robinson 1941, 381, pl. 120.1896.

156 Robinson 1941, 380-81.

157 Zunal 2017, 44, fig. 3.

158 Haspels 1951, 42a.9.
} 
Type IB2h is quite eroded. The midrib is conical, while the blades of this type are bilobate. The body is leaf-shaped. Its height is around $3,5 \mathrm{~cm}$; the width is $1,7 \mathrm{~cm}$; the weight is $5,24 \mathrm{gr}$. This sample was uncovered in the area where the Persian Terrace is located in Daskyleion.

Three samples of Type IB2i were uncovered in Acro-Daskyleion. The midrib is spindleshaped, and the body triangular-shaped. The blades of these arrowheads are bilobate. The most distinctive characteristic of this type is that the blades edges, or shoulders, at the widest point of the two blades are angled. Moreover, a short socket is evident. The height of these heads is about $4 \mathrm{~cm}$, and their width between the two blades is 1,3 and $1,9 \mathrm{~cm}$. The socket size is $0,8 \mathrm{~cm}$. Their weight ranges from 4,80 to $5,61 \mathrm{gr}$.

\section{Discussion}

After the arrival of Persians in 547/6 to the region, the number of arrowheads increases relatively in Daskyleion. The most evident detail observed in this augmentation is that Daskyleion Type IB1a and IB1b constitute the largest group among the arrowheads. The most obvious detail noted in this increase is that arrowhead types become common in the sites which have either a Persian destruction layer or layers related to the Persians. Common types with Daskyleion arrowheads were detected consequently. ${ }^{159}$ For example, types common with Sardis are IB1a, IB1b, IB1c, IB2a, IB2b and IB2f. The arrowheads in Sardis, similar to the Daskyleion samples, belong to layers related to the Persians or those that reflect the LydianPersian conflict. Similar types have been observed in the excavations at Karamattepe and Ballicaoluk where layers related to the Persians are located. Baykan stated that there was a Persian munition factory there and argued that iron and bronze arrowheads were discovered there in large numbers. ${ }^{160}$ Bronze arrowheads with sockets similar to the Daskyleion samples are Nif (Karamattepe) Types 5, 6, 8 and 9. ${ }^{161}$ Apart from these samples, a pyramidal-tanged iron arrowhead called Nif type 1 (Karamattepe and Ballicaoluk), ${ }^{162}$ of which 296 were uncovered, also constitutes the largest group among Daskyleion iron arrowheads (fig. 11). ${ }^{163}$ Another centre attacked by the Persians and displaying arrowheads similar to the Daskyleion samples is Kerkenes. ${ }^{164}$ Samples similar to Daskyleion types IB1a, IB1b, IB2a and IB2e were uncovered there. Kelainai is also another centre in which arrowheads similar to the Daskyleion samples were found in layers related to the Persians. ${ }^{165}$ Samples similar to Daskyleion types IB1a, IB1e and IB2d were reported there.

However, with the arrowheads found at Daskyleion until today, an incontestable attack has not been observed, as at Sardis, Gordion and Smyrna. During the excavations carried out in the downtown area of Gordion, a large number of bilobate arrowheads was found buried in a wall on the attack ramp built by the Persians to reach the town in 540 century BC. ${ }^{166}$ In

\footnotetext{
159 I am indebted to Prof. Nick Cahill for his kind permission for the study on the database of excavations at Sardis in 2019.

160 Baykan 2017a, 29.

161 Baykan 2017a, 29-32, fig. 3; 2017b, 125, fig. 9.

162 Baykan 2017a, 24.

163 In Daskyleion, among the well-preserved iron arrowheads, eight of this type were identified.

164 Schmidt 1929, 237, 270, figs. 69, K59, K73, K33, K64, K87.

165 Summerer 2011, 35, fig. 2.

166 https://www.penn.museum/sites/gordion/iron-age-gordion/ (accessed 21.04.2020).
} 
a similar vein, arrowheads were also found in Sardis ${ }^{167}$ and Old Smyrna ${ }^{168}$ that are associated with attack and destruction. Deformations encountered on some of these arrowheads are among the most significant indicators that important constructions were preserved here. Additionally, a couple of bronze- and iron-scale armour found in Daskyleion demonstrate the existence of fully equipped soldiers there, at least for some time (fig. 12). ${ }^{169}$ Based on this data in Daskyleion, at least some of the arrowheads were used as combat weapons.

The emergence of several scales of armour and deformations on the arrowheads at Daskyleion point to some historical events mentioned by ancient authors. There are two important events reported by historical sources about Daskyleion. The first is the expedition to Daskyleion by Agesilaos (396-395 BC). As was stated, during Bakır's excavations, a 50 cm-thick burnt layer was reported under the footing blocks of a construction shaped like a tower in Trench M-8. This fire has been associated with the destruction of the town by the Spartan king Agesilaos in 395 BC. However, Sarkaya argues, based on her reading of the ancient sources, that Agesilaos could not besiege or conquer Daskyleion, which is contrary to the view of other modern scholars. ${ }^{170}$

The second event occurred when Alexander the Great's general Parmenion seized Daskyleion but then abandoned it after the Granikos War. ${ }^{171}$ However, Bakir denies its abandonment after Granikos ${ }^{172}$ and claims that Parmenion besieged Acro-Daskyleion and partly ruined the Persian Wall. Finally the Macedonians captured the site.

According to the density map of leaded bronze arrowheads, the largest number of arrowheads was reported in the area called the Hellenistic Tower on the Acropolis. These were found in the trenches around the Cultic Road and the buildings in Trench F. But they were never found en masse. Bakir's excavations uncovered partly burnt layers from the 4th century in front of the Persian wall (324 BC?) and in trenches around the Cultic Road (395 BC?) (fig. 13). The archaeological excavations confirmed that new large-scale reconstruction activity started on Acro-Daskyleion in the early and late 4th century BC. The main reason for this activity may be the damage done by the serious attacks. Interestingly, the samples dated to the 4th century are more than those dated to the 5th century BC at Daskyleion. The increase in the number of arrowheads in the 4th century BC at Daskyleion may be related to these political events.

\section{Conclusion}

The typology defining bronze arrowheads in the finds of Daskyleion in this study also takes into consideration their morphology and composition and serves as a classification based on the function of the arrowhead. This classification makes it possible to differentiate the arrowheads used in Daskyleion for war and hunting. Trilobate arrowheads that may have targeted armor-like hard surfaces in warfare are in the majority. Some arrowheads at Daskyleion show

\footnotetext{
167 Cahill 2010; Nicholls 1958-1959, 129-34; Cook 1958-1959, 24, table 6d.

168 Tanriver et al. 2017, 98; Akar-Tanriver 2017, 88.

169 Until today, seven scale armour in total have been discovered in Daskyleion. Three of these are rectangular and made of iron. The shape of the other four is fish scale and made of bronze. The fact that these scales were made of different materials demonstrates that they belonged to different pieces of armour.

170 Sarkaya 2015

171 Arr., Anab. 1.17.1; Strabo, Geography 16.776; Paus., Description 1.29.10.

172 Bakir 2003, 8.
} 
signs of bending and thereby support the premise that this type was probably used in war to pierce armour.

Zooarchaeological studies at Daskyleion have enlightened us that at least some species of large wild animals were hunted using wide arrowheads with cutting edges. Conversely, small arrowheads were used to hunt small animals.

According to pottery deposits, the circulation time of the leaded bronze arrowheads was the 5th and 4th centuries BC. The earliest samples among the Daskyleion arrowheads are IB2a from the bilobates. The types used longest in Daskyleion were IB1a and IB1b, which are both trilobates. These arrowhead types were also used in other sites during the 6th or even the 7th centuries BC. Some Daskyleion arrowhead types are common at sites that have either a Persian destruction layer or a layer related to the Persians. Different types of arrowheads were deposited together in the grave chamber of Tumulus T6. Thanks to the finds of T6, some types of arrowhead could be dated more precisely. Consequently, those arrowheads suggest which were used contemporaneously at Daskyleion as well. Obviously, they are Types IA1a and IB2a among the bilobates along with Types IB1a and IB1b among the trilobate samples. Daskyleion arrowheads consist of arrowhead types well-distributed around a wide geographical area from Mainland Greece to the Near East.

One may anticipate that the large diversity in the typology of Daskyleion arrowheads could be related with their function. On the other hand, this diversity could also be explained through the multicultural structure of society at Daskyleion. 


\section{Bibliography}

Adams, W.Y., and E.W. Adams. 1991. Archaeological Typology and Practical Reality: A Dialectical Approach to Artifact Classification and Sorting. Cambridge: Cambridge University Press.

Adams, W.Y. 2008. "Classification and Typology." In Encylopedia of Archaeology. Vol. 2, edited by D.M. Pearsall, 1019-27. San Diego, CA: Elsevier.

Akar-Tanrıver, D.S. 2009. "Apollon Klarios Kültü, Kehanet Pratikleri ve Adaklar.” Ph.D. diss., Ege University.

Akar-Tanrıver, D. 2017. "Eski Smyrna'da Savaşlar, Silahlar ve Askeri Donanımlar." Arkeoloji ve Sanat 156:77-91.

Akok, M. 1965. "Afyon-Çavdarl1 Höyük Kazısı.” TürkArkDerg 14.1-2:5-34.

Akurgal, E. 1983. Alt-Smyrna I. Wohnschichten und Athenatempel. Ankara: Türk Tarih Kurumu.

Alcock, J.P. 2006. Food in the Ancient World. Westport, CONN.: Greenwood Press.

Arslan, B., S. Aybek, and E. Durak. 2017. "Metropolis'de Bulunan Ok Uçları." Masrop E-Dergi. Mimarlar Arkeologlar Sanat Tarihçileri ve Restoratörler Ortak Platformu E-Dergisi 9.13:54-73.

Atik, N. 2017. "Heraion Teikhos Kazılarında Bulunan Ok Uçları." Masrop E-Dergi. Mimarlar Arkeologlar Sanat Tarihçiler ve Restoratörleri Ortak Platformu E-Dergisi 11.16:57-76.

Attaelmanan, A.G., E.A. Yousif, and S.A. Jassim. 2013. "Investigation of Tin, Arsenic and Lead Concentrations in Prehistoric Arrowheads." Journal of Analytical Atomic Spectrometry 28: 1436-440.

Baitinger, H. 1999. "Waffen und Bewaffnung aus der Perserbeute in Olympia." AA:125-39.

Baitinger, H. 2001. Die Angriffswaffen aus Olympia. Berlin: De Gruyter.

Bakır, T. 2011. Daskyleion: Balıkesir'in Eski Çağlardaki Valilik Merkezi. Balıkesir: Balıkesir Valiliği.

Bakır, T. 2003. "Daskyleion (Tyaiy Drayahya) Hellespontine Phrygia Bölgesi Akhaemenid Satraplı̆g1." Anadolu 25:1-26.

Bakır, T., R.G. Gürtekin-Demir, and C. Tanrıver. 2003. "Daskyleion 2001.” Kazı Sonuçları Toplantısı 24.1:491-500.

Bakır, T., K. İren, and Ç. Atay. 2013. "Yağmalanan Daskyleion Tümülüsleri." Aktüel Arkeoloji 34:26-27.

Baykan, D. 2017a. "Nif Dağ1 Kazısı Karamattepe ve Ballıcaoluk’ta Bulunan Ok Uçları." Masrop E-Dergi. Mimarlar Arkeologlar Sanat Tarihçiler ve Restoratörler Ortak Platformu E-Dergisi 9.12:18-40.

Baykan, D. 2017b. "Metal Buluntular ve Arkeometalürji Verileri." In Nif Dă̆ı Ballıcaoluk (2008-2016) Prof. Dr. Elif Tül Tulunay Onuruna, edited by M. Peker, C. Baykan, and D. Baykan, 119-60. Istanbul: Homer Yayınları.

Bernardini, C. 2006. I bronzi della stipe di Kamiros. Monografie della Scuola Archeologica di Atene e delle Missioni Italiane in Oriente 18. Athens: Scuola Archeologica Italiana di Atene.

Blackmore, H.L. 2000. Hunting Weapons from the Middle Ages to the Twentieth Century. Mineola, NY.: Dover Publications.

Blinkenberg, C., and K.F. Kinch. 1931. Lindos, Fouilles de l'Acropole 1902-1914. Vol. 1, les petits objets. Berlin: De Gruyter.

Boehlau, J., and K. Schefold. 1942. Larisa am Hermos. Vol. 3, Die Kleinfunde. Berlin: De Gruyter.

Boehmer, R.M. 1972. Die Kleinfunde von Boğazköy aus den Grabungskampagnen 1931-1939 und 19521969. Boğazköy-Hattuša 7. WVDOG 87. Berlin: Mann.

Broneer, O. 1933. "Excavations on the North Slope of the Acropolis in Athens, 1931-1932." Hesperia 2.3:329-417. 
Broneer, O. 1935. "Excavations on the North Slope of the Acropolis in Athens 1933-1934." Hesperia 4.2:109-88.

Bumke, H., and E. Röver. 2002. "Didyma. Bericht über die Arbeiten 2000. Ein wiederentdecktes Heiligtum auf dem >Taxiarchis` in Didyma." AA 2002.1:84-104.

Cahill, N. 2010. "Sardeis’te Pers Tahribi.” In Lydialılar ve Dünyalar, edited by N.D. Cahill, $339-61$. Istanbul: Yap1 Kredi Kültür Sanat Yayıncıl1k.

Cahill, N. 2015. "Sardis 2013." Kazı Sonuçları Toplantısı 36.2:413-30.

Cahill, N. 2018. "Second Newsletter from Sardis 2017." Archaeological Exploration of Sardis, January 11, 2018. https://fds.lib.harvard.edu/fds/deliver/440424480/Sardis_Newsletter_2017_2.pdf

Campbell, D.B. 2008. Ancient Siege Warfare: Persians, Greeks, Carthaginians and Romans 546-146 BC. Oxford: Osprey.

Cleuziou, S. 1977. "Les pointes de flèches 'scythiques' au Proche et Moyen Orient." In Le plateau iranien et l'Asie centrale des origines à la conquête Islamique. Leurs relations à la lumière des documents archéologiques, Paris 22-24 Mars 1976, edited by J. Deshayes, 187-99. Colloques internationaux du Centre national de la Recherche scientifique 567. Paris: Editions du CNRS.

Conze, A. 1913. Stadt und Landschaft. AvP 1.2. Berlin: Reimer.

Cook, J.M. 1958-1959. “Old Smyrna, 1948-1951.” BSA 53/54:1-34.

Coşkun, G. 2005. "Daskyleion'da Orta Akhemenid Dönem.” Ph.D. diss., Ege University.

Crowfoot, J.W., G.M. Crowfoot, and K.M. Kenyon. 1957. The Objects from Samaria. Samaria-Sebaste; Reports of the Work of the Joint in 1931-1933 and of the British Expedition in 1935, no. 3. London: Palestine Exploration Fund.

Curtis, J., and N. Tallis. 2005. Forgotten Empire: The World of Ancient Persia. Berkeley/Los Angeles: British Museum Press.

Curtius, E., and F. Adler. 1890. Olympia: Die Ergebnisse der von dem Deutschen Reich veranstalteten Ausgrabung. Vol. 4, Die Bronzen und die übrigen kleineren Funde von Olympia. Berlin: A. Asher.

Dardeniz, G. 2017. "M.Ö. II. ve I. Bin Ok Uçlarında Arkeometrik Bulgular.” Masrop E-Dergi. Mimarlar Arkeologlar Sanat Tarihçiler ve Restoratörler Ortak Platformu E-Dergisi 8.10:7-17.

Davidson, G.R. 1952. Corinth. Vol. 12, The Minor Objects. Princeton, NJ: ASCSA.

Davis, T.A. 2013. "Archery in Archaic Greece.” Ph.D. diss., Columbia University.

Dawkins, R.M. 1929. The Sanctuary of Artemis Orthia at Sparta. London: Macmillan.

Delrue, P. 2007. "Trilobate Arrowheads at ed-Dur (U.A.E, Emirate of Umm al-Qaiwain)." Arabian Archaeology Epigraphy 18.2:239-50.

Dörpfeld, W. 1902. Troia und Ilion: Ergebnisse der Ausgrabungen in den vorhistorischen und bistorischen Schichten von Ilion 1870-1894. Athens: Beck \& Barth.

Erdmann, E. 1973. "Die sogenannten Marathonpfeilspitzen in Karlsruhe.” $A A$ 88:30-58.

Erzen, A. 1978. Çavuştepe I. M.Ö. 7-6. Yüzyıl Urartu Mimarlık Anıtlar ve Ortaçă̆ Nekropolü. Ankara: Türk Tarih Kurumu.

Evliya Çelebi Seyahatname, edited by S.A. Kahraman and Y. Dağl1. 2nd ed. 2011. Istanbul: Yap1 Kredi Yayınlar1.

Forsom, E., and M.J. Smith. 2017. "Getting to the Point: An Experimental Approach to Improving the Identification of Penetrating Projectile Trauma to Bone Caused by Medieval Arrows.” JAS 11:274-86.

Frankfort, H. 1970. The Art and Architecture of the Ancient Orient. Harmondsworth: Penguin.

Gale, N.H., Z.A. Stos-Gale, and G.R. Gilmore. 1985. "Alloy Types and Copper Sources of Anatolian Copper Alloy Artifacts." AnatSt 35:143-73. 
Gilbert, R. 2004. A to Z Guide to White-Tailed Deer and Deer Hunting. Upper Saddle River, NJ: Creative Outdoors.

Goldman, H. 1963. Excavations at Gözlü Kule, Tarsus. Vol. 3, The Iron Age. Text and Plates. Princeton: Princeton University Press.

Greenewalt, C.H., Jr. 1997. "Arms and Weapons at Sardis in the Mid Sixth Century B.C./M.Ö. 6. Yüzy1l Ortasında Sardis'de Askeri Teçhizat ve Silahlar." Arkeoloji ve Sanat 79:2-20.

Guralnick, E. 1987. Sardis: Twenty-Seven Years of Discovery. Chicago: Chicago Society of the Archaeological Institute of America.

Hančar, F. 1972. "Die Bogenwaffe der Skythen." MAGW 102:3-25.

Hanfmann, M.A., and A.H. Detweiler. 1961. "From the Heights of Sardis." Archaeology 14:3-11.

Haspels, C.H.E. 1951. Phrygie, exploration archéologique. Vol. 3, La cités de Midas, céramique et trouvailles diverses. Institut française d'archéologie de Stamboul. Paris: Boccard.

Hellmuth, A. 2014. "Horse, Bow and Arrow - A Comparison between the Scythian Impact on the Mediterranean and on Eastern Middle Europe." Mediterranean Review 7.1:1-38.

Hulit, T.D. 2002. "Late Bronze Age Scale Armour in the Near East: An Experimental Investigation of Materials, Construction, and Effectiveness, with a Consideration of Socio-Economic Implications." Ph.D. diss., Durham University.

Ivantchik, A. 2016. "Arrowheads from a Survey in Celaenae-Apameia." In Kelainai II. Kelainai-Apameia Kibotos: Eine achämenidische, hellenistische und römische Metropole, edited by A. Ivantchik, L. Summerer, and A. von Kienlin, 473-89. Bordeaux: Ausonius Éditions Bordeaux.

İren, K., and H. Y1ldızhan. 2017. "Pers Daskyleionu: Güney Marmara Bölgesi'nde bir Satraplık Merkezi." In Persler Anadolu'da: Kudret ve Görkem, edited by K. İren, Ç. Karaöz, and Ö. Kasar, 332-50. Istanbul: Yapı Kredi Kültür Sanat Yayıncilık.

Kasar, Ö. 2018. "Daskyleion'da Görülen Mezar Tipleri ve Ölü Gömme Gelenekleri.” In Antik Çağ'dan Cumburiyet'e Bandırma ve Yakın Çevresi Tarihi, edited by U.T. Sivrioğlu, 57-71. Bursa: Dora Press.

Klebinder-Gauss, G. 2007. Bronzefunde aus dem Artemision von Ephesos. Ephesos 12.3. Vienna: Verlag der Österreichischen Akademie der Wissenschaften.

Konyar, E., K. Işık, R. Kuvanç, B. Genç, and B. Gökce. 2018. Zaiabina'nın Bronzları: Doğubayazıt Urartu Metal Eserleri, Abmet Köroğlu Koleksiyonu. Istanbul: Doğubeyazıt Belediyesi Kültür Yayınları.

Lubos, M. 2009. "Weihungen griechischer Söldner in Didyma." Zurück zum Gegenstand, Festschrift für Andreas E. Furtwängler. Vol. 2, edited by R. Einicke, S. Lehmann, H. Löhr, G. Mehnert, A. Mehnert, and A. Slawisch, 405-14. Schriften des Zentrums für Archäologie und Kulturgeschichte des Schwarzmeerraumes 16. Langenweissbach: Beier\&Beran.

Malloy, A.G. 1993. Weapons. Ancient and Medieval Art and Antiquities. Sale catalogue 24. South Salem, NY: Alex G. Mallot Inc.

Maier, F.G., and V. Karageorghis. 1984. Paphos: History and Archaeology. Nicosia: A.G. Leventis Foundation.

Miller, S.G. 1975. "Excavations at Nemea 1973-1974." Hesperia 44.2:143-72.

Minns, E.H. 1913. Scythians and Greeks: A Survey of Ancient History and Archaeology on the North Coast of the Euxine from the Danube to the Caucasus. Cambridge: Cambridge University Press.

Moorey, P.R.S. 1980. Cemeteries of the First Millennium B.C. at Deve Hüyük, near Carchemish, Salvaged by T.E. Lawrence and C.L. Woolley in 1913 (With a Catalogue Raisonné of the Objects in Berlin, Cambridge, Liverpool, London, and Oxford). BAR-IS 87. Oxford: BAR.

Nicholls, R.V. 1958-1959. "Old Smyrna: The Iron Age Fortifications and Associated Remains on the City Perimeter." BSA 53/54:35-137. 
Olson, B.R., and T. Najbjerg. 2017. "A Deposit of Scythian-Type Arrowheads from Polis Chrysochous (Ancient Arsinoe).” RDAC 2011-2012:639-56.

Otto, T., H. Thrane, and H. Vandkilde, eds. 2006. Warfare and Society: Archaeological and Social Anthropological Perspectives. Aarhus: Aarhus University Press.

Özdemir, M.A., and M. Işıkl1. 2017. "Van Ayanis Kalesinden Ele Geçen Ok Uçları Üzerine Genel Bir Değerlendirme." Masrop E-Dergi. Mimarlar Arkeologlar Sanat Taribçiler ve Restoratörler Ortak Platformu E-Dergisi 8.11:46-62.

Özyiğit, Ö. 1994. "The City Walls of Phokaia.” RÉA 96.1-2:77-109.

Paterson, W.F. 1984. Encyclopaedia of Archery. New York: St. Martin's Press.

Petrie, W.M.F. 1888. Tanis. Part 2, Nebesheh (Am) and Defenneh (Tahpanhes). Memoir of the Egypt Exploration Fund 4. London: Trübner.

Petrie, W.M.F. 1928. Gerar. British School of Archaeology in Egypt and Egyptian Research Account 43. London: British School of Archaeology in Egypt.

Prêtre, Cl. 2016. La fibule et le clou: Ex-voto et instrumentum de l'Artémision. Études Thasiennes 23. Athens: École française d'Athènes.

Rausing, G. 1967. The Bow: Some Notes on Its Origins and Development. Acta Archaeologica Lundensia 8.6. Bonn: Rudolf Habelt / Lund: CWK Gleerups.

Ray, F.E. 2009. Land Battles in 5th Century B.C. Greece: A History and Analysis of 173 Engagements. Jefferson, NC: McFarland.

Riesch, H. 2019. "Shooting Experiments with Early Medieval Arrowhead.” EXARC 2019.3:1-4.

Robinson, D.M. 1941. Excavations at Olynthus. Part 10, Metal and Minor Miscellaneous Finds. An Original Contribution to Greek Life. Johns Hopkins University Studies in Archaeology 31. Baltimore: Johns Hopkins.

Rothenberg, B. 1975. "Metals and Metallurgy." In Investigations at Lachish: The Sanctuary and the Residency (Lachish V), edited by Y. Aharoni, 72-83. Publications of the Institute of Archaeology 4. Tel Aviv: Gateway Publishers.

Rudgley, R. 2000. The Lost Civilizations of the Stone Age. New York: Simon \& Schuster.

Sarıkaya, S. 2015. “Agesilaos'un Daskyleion Seferleri (MÖ 396-395).” Phaselis 1:199-219.

Sawyer, R.D., and M.L. Sawyer. 2011. Ancient Chinese Warfare. New York: Basic Books.

Schmidt, E.F. 1929. "Test Excavations in the City on Kerkenes Dagh." AJSL 45.4:221-74.

Schmidt, E.F. 1957. Persepolis. Vol. 2, Contents of the Treasury and Other Discoveries. OIP 69. Chicago: University of Chicago Press.

Schmidt, E.F., and W.M. Krogman. 1933. The Alishar Hüyük: Seasons of 1928 and 1929, Part 2. Researches in Anatolia Vol. 5. OIP 20. Chicago: University of Chicago.

Scott, D.A. 1991. Metallography and Microstructure of Ancient and Historic Metals. Malibu: J. Paul Getty Trust.

Scott, D.A. 2010. Ancient Metals: Microstructure and Metallurgy. Los Angeles: Conservation Science Press.

Schliemann, H. 1884. Troja: Results of the Latest Researches and Discoveries on the Site of Homer's Troy, and in the Heroic Tumuli and Other Sites, Made in the Year 1882 and a Narrative of a Journey in the Troad in 1881. London: John Murray.

Snodgrass, A.M 1964. Early Greek Armour and Weapons from the End of the Bronze Age to 600 B.C. Edinburg: Edinburg University Press.

Smirnov, K.F., and V.G. Petrenko. 1963. Savromaty Povolžja i južnogo Priyral'ja. Moskva: Izdat.

Soyer, A. 2004. Food, Cookery, and Dining in Ancient Times: Alexis Soyer's Pantropheon. Original edition, New York: Paddington Press, 1853. Mineola, NY: Dover Publications. 
Sözüer, Ö. 2018. "Curt Kosswig, Bandırma Kuş Cenneti ve Bandırma'nın Doğal Mirası Üzerine "Etnobiyolojik" Bir Deneme." In Antik Çağ'dan Cumburiyet'e Bandirma ve Yakın Çevresi Tarihi, edited by U.T. Sivrioğlu, 589-602. Bursa: Dora Press.

Stern, E. 1982. Material Culture of the Land of the Bible in The Persian Period 538-332 BC. Warminster: Aris \& Phillips / Jerusalem: Israel Exploration Society.

Stronach, D. 1978. Pasargadae. A Report on the Excavations Conducted by the British Institute of Persian Studies from 1961 to 1963. Oxford: Clarendon Press.

Sulimirski, T. 1954. "Scythian Antiquities in Western Asia." Artibus Asiae 17.3-4:282-318.

Summerer, L. 2011. "Die Persische Armee in Kelainai." In Kelainai I. Kelainai-Apameia Kibotos: Stadtentwicklung im anatolischen Kontext. Akten des internationalen Kolloquiums, München, 2-4 April 2009, edited by L. Summerer, A. Ivantchik, and A. von Kienlin, 33-55. Bordeaux: Ausonius.

Summers, G.D. 2017. "Iron Age Arrowheads from Kerkenes." In Overturning Certainties in Near Eastern Archaeology. A Festschrift in Honor of K. Ashhan Yener. Culture and History of the Ancient Near East 90. Edited by C.. Maner, M.T. Horowitz, and A.S. Gilbert, 645-64. Leiden/Boston: Brill.

Tanriver, C., S. Akat-Özenir, D.S. Akar-Tanriver, A.Ü. Erdem-Otman, and A. Erdoğan. 2017. "Eski Smyrna (Bayraklı Örenyeri / Tepekule) Kazısı 2014-2015." Kazı Sonuçları Toplantısı 38.3:95-114.

Thompson, H.A. 1940. The Tholos of Athens and Its Predecessors. Hesperia Suppl. 4. Baltimore: American School of Classical Studies at Athens.

Trigger, B.G. 2006. A History of Archaeological Thought. 2nd ed. Cambridge/New York: Cambridge University Press.

Ureche, P. 2013. "The Bow and Arrow during the Roman Era." Ziridava Studia Archaeologica 27:183-195.

Valério, P., R.J.C. Silva, M.F. Araújo, A.M.M. Soares, and L. Barros. 2012. "A Multianalytical Approach to Study the Phoenician Bronze Technology in the Iberian Peninsula-A view from Quinta do Almaraz." Materials Characterization 67:74-82.

Waldbaum, J.C. 1983. Metalwork from Sardis. The Finds Through 1974. SardisMon 8. Cambridge, MASS: Harvard University Press.

Woolley, L. 1938. "The Excavations at Al Mina, Sueidia. II." JHS 58.2:133-70.

Yalçıkl1, D. 2006. Pfeilspitzen, Eisenzeitliche Pfeilspitzen aus Anatolien. Universitätsforschungen zur prähistorischen Archäologie 128. Bonn: Habelt.

Yalçıklı, D. 2016. Anadolu'da Demir Çă̆ı Metal Silâhları. Saarbrücken: Türkiye Alim Kitapları.

Young, R.S. 1953. "Making History at Gordion." Archaeology 6.3:159-66.

Yukishima, K. 1992. "Scythian Bronze Arrowheads from Kaman-Kalehöyük." Anatolian Archaeological Studies 1. Kaman-Kaleböyük 1:89-100.

Zunal, O. 2017. "Klaros'ta Bulunan Ok Uçlar1." Masrop E-Dergi. Mimarlar Arkeologlar Sanat Tarihçiler ve Restoratörler Ortak Platformu E-Dergisi 9.13:41-53.

Makale Geliş / Received : 27.12.2019

Makale Kabul / Accepted : 31.03.2020 


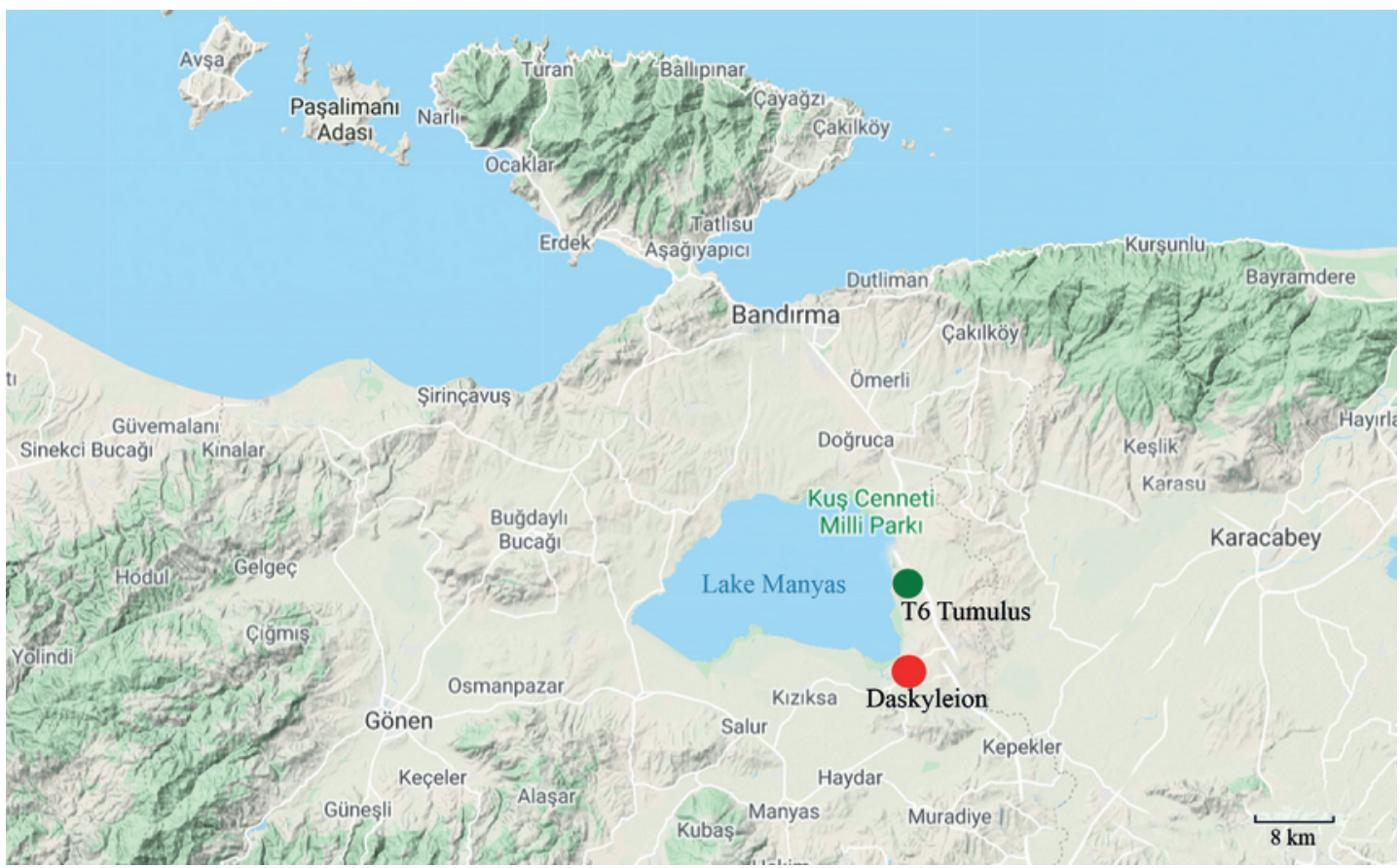

FIG. 1 Daskyleion and Tumulus T6.

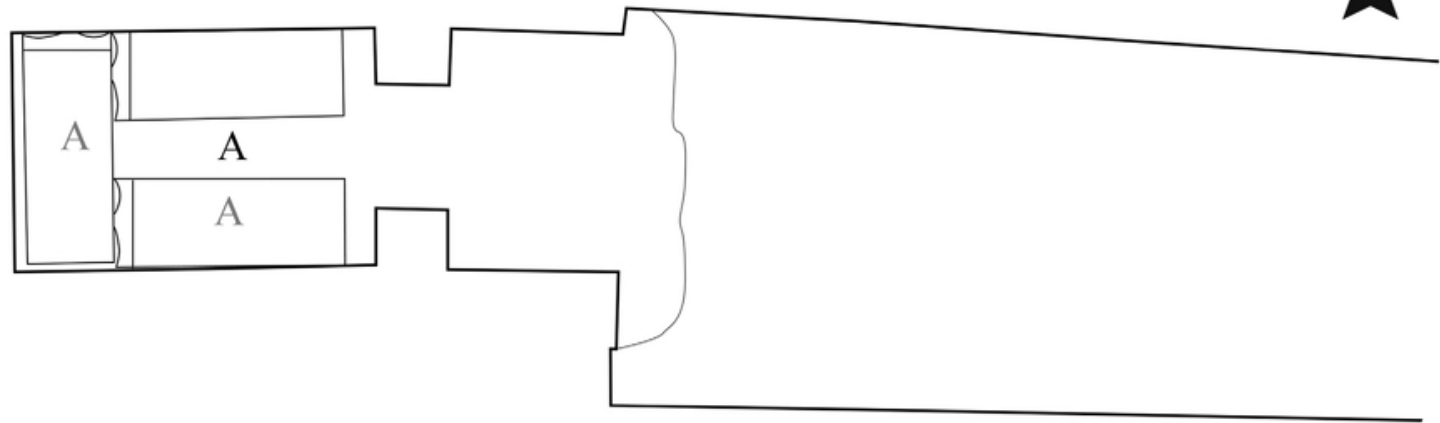

A : Arrowheads under the kline

A : Arrowheads in the middle of the grave chamber

FIG. 2 Location of arrowheads in the grave chamber of Tumulus T6. 

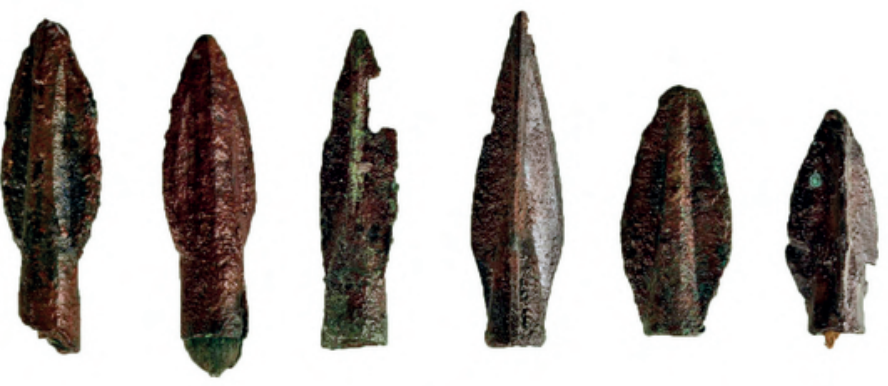

FIG. 3

Bilobate and

trilobate

arrowheads from

Tumulus T6.
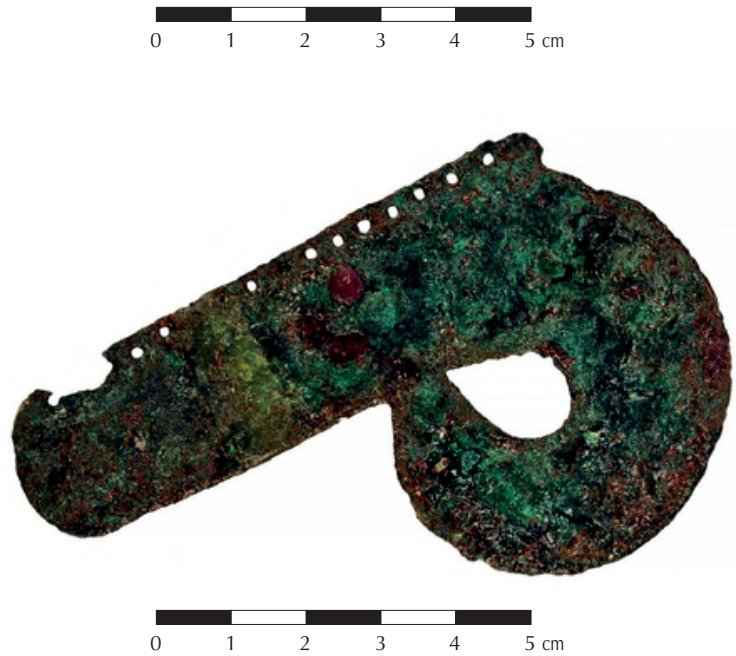

FIG. 4

Bronze ornament of a gorytos discovered in Tumulus T6.

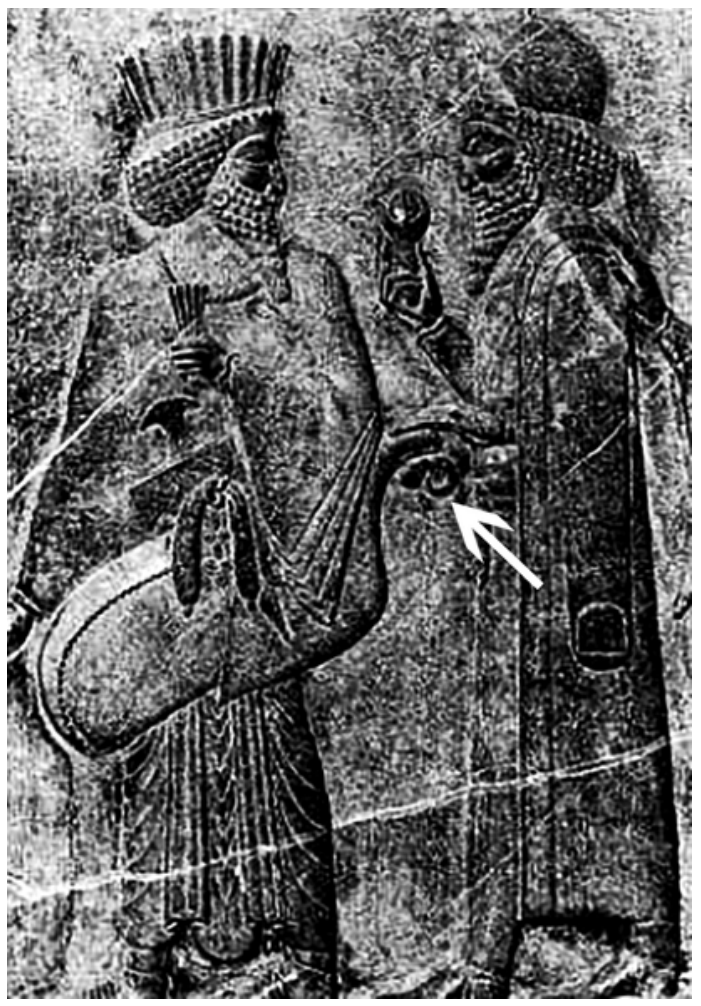

FIG. 5

Gorytos depicted on the relief. 


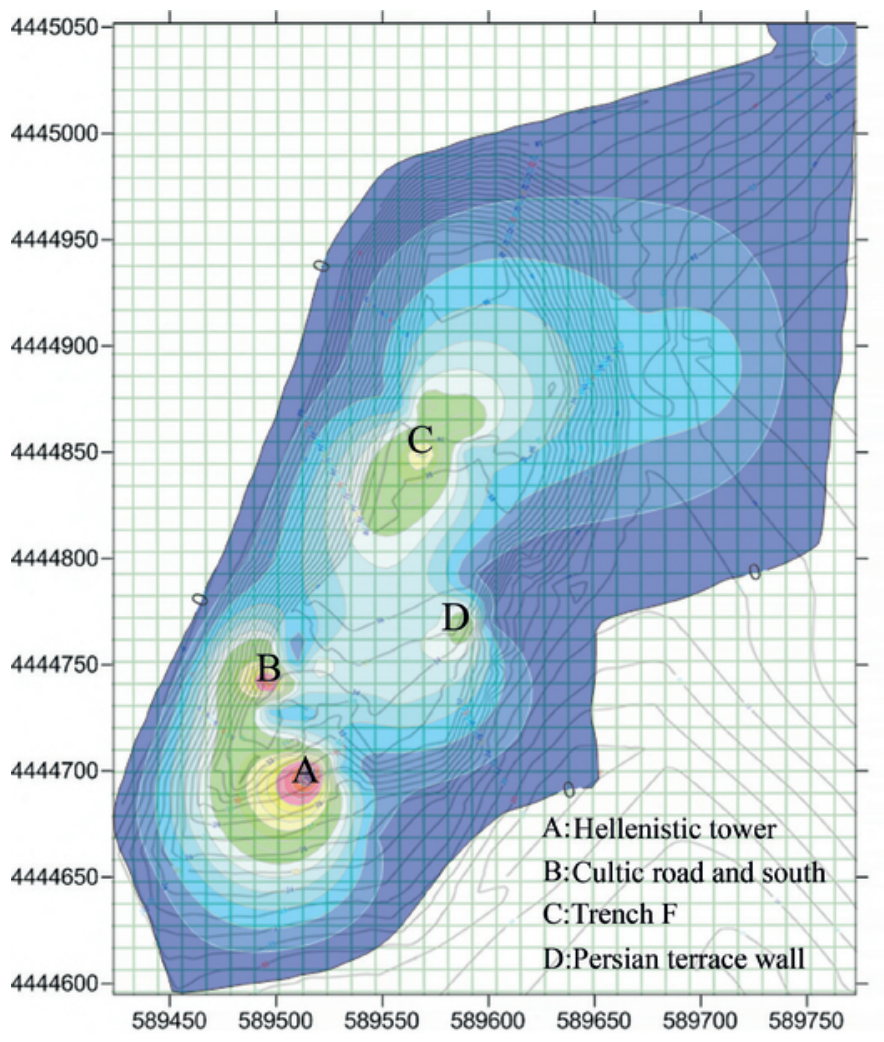

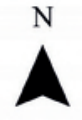

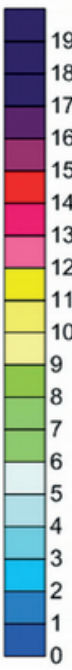

Cultic road and south

C:Trench $\mathrm{F}$

$89650589700 \quad 589750$

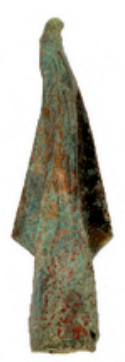

a
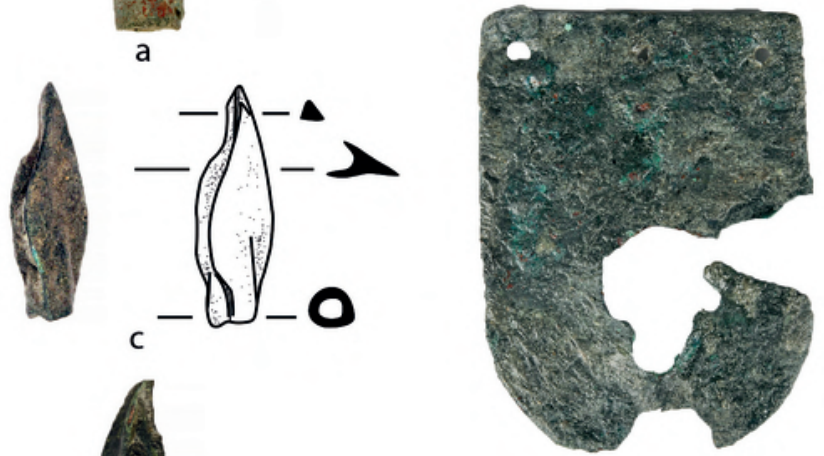

b
FIG. 6

Map showing the density of leaded bronze arrowheads found in Daskyleion.
FIG. 7a-d

Destruction and deformation observed on the arrowheads and a scale. 


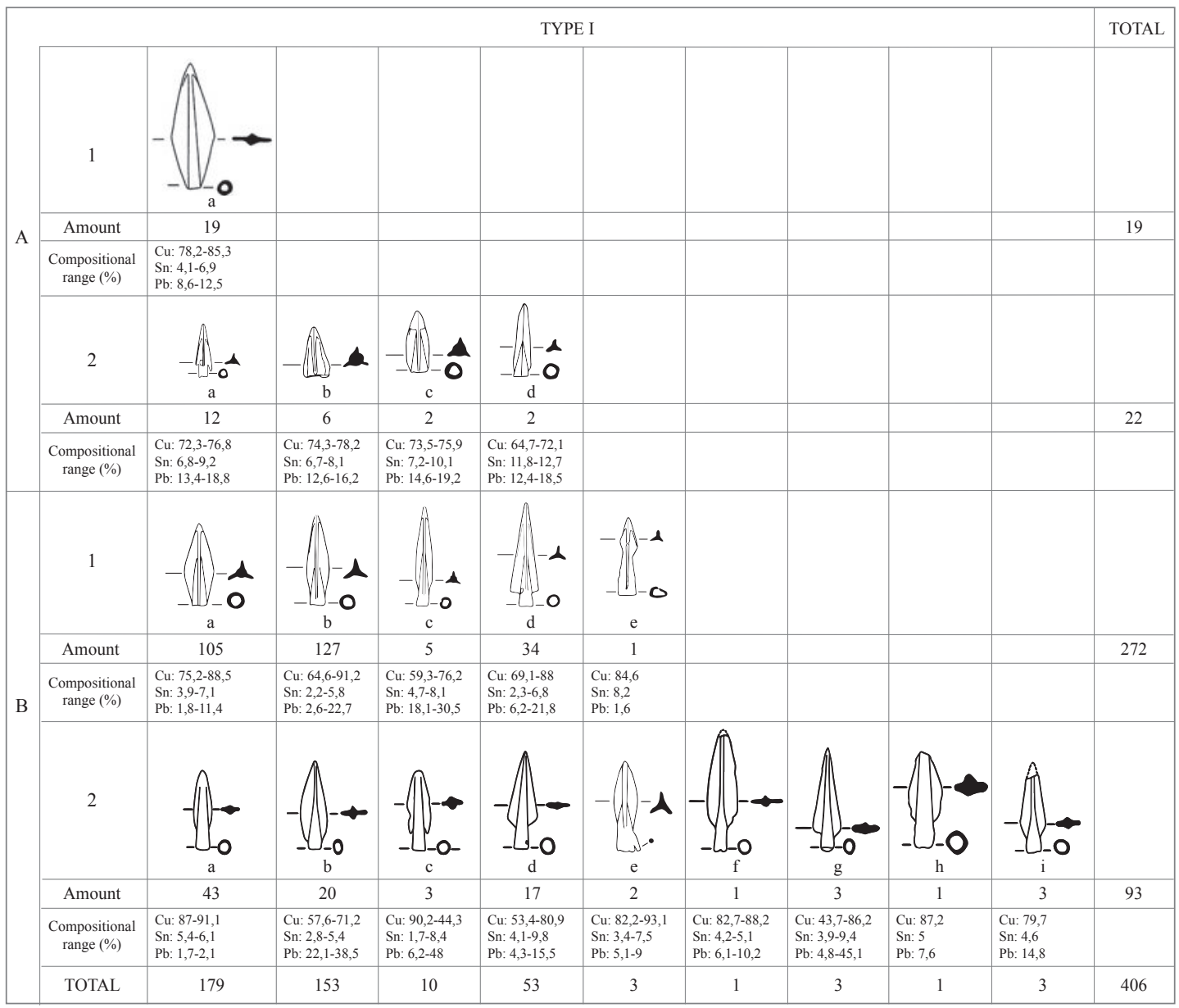

FIG. 8 Table of Daskyleion arrowhead typology.

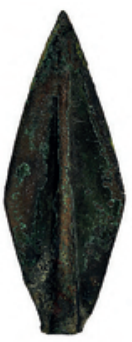

IAla

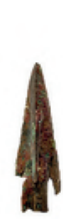

IA2a

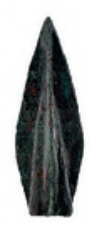

IB1a

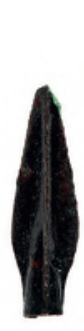

IB $1 \mathrm{~b}$

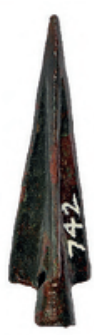

IB1d

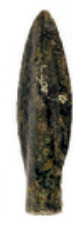

IB2a

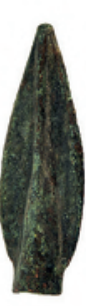

IB2b

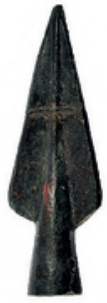

IB2d

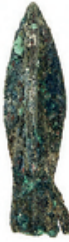

IB2e

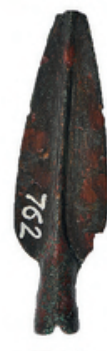

IB2f
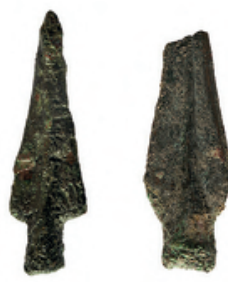

IB2 $\mathrm{i}$
FIG. 9

Types of leaded bronze arrowheads. 


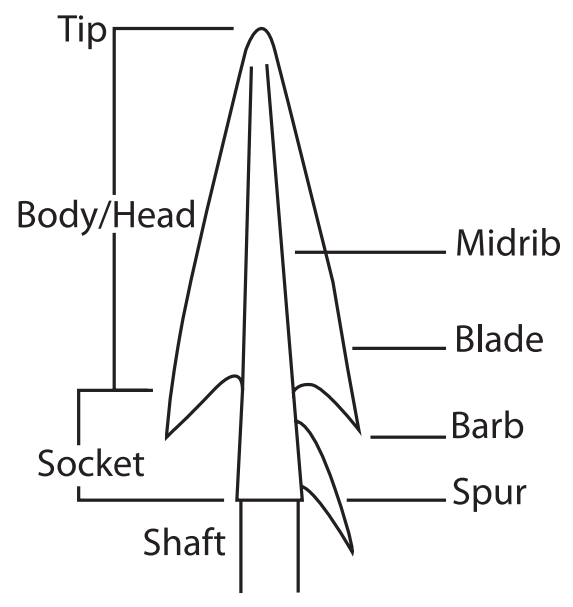

FIG. 10 Parts of the arrow.

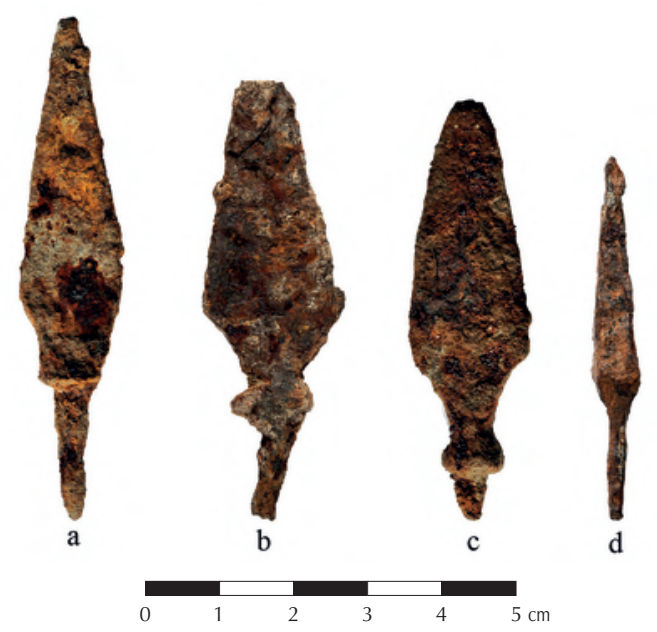

FIG. 11 Iron arrowheads from Daskyleion.
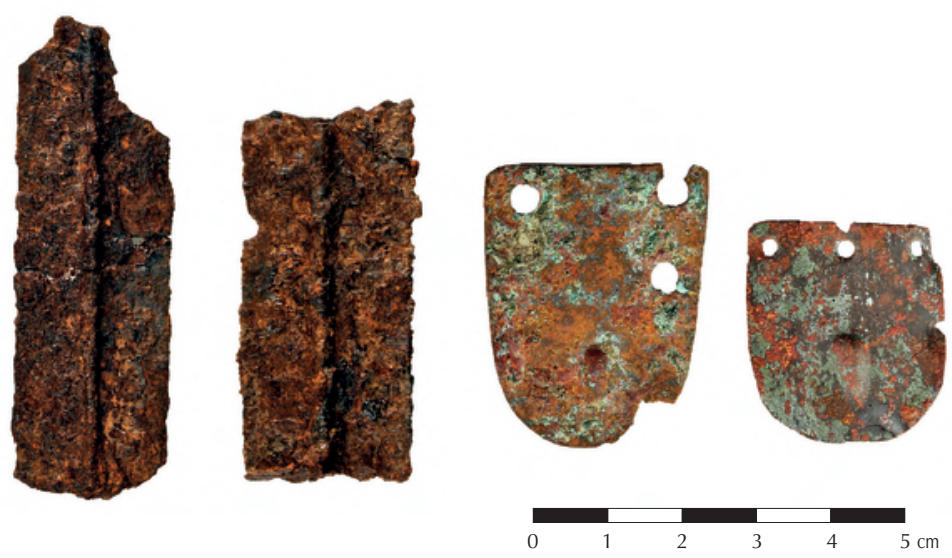

FIG. 12 Iron and bronze scale armor from Daskyleion. 


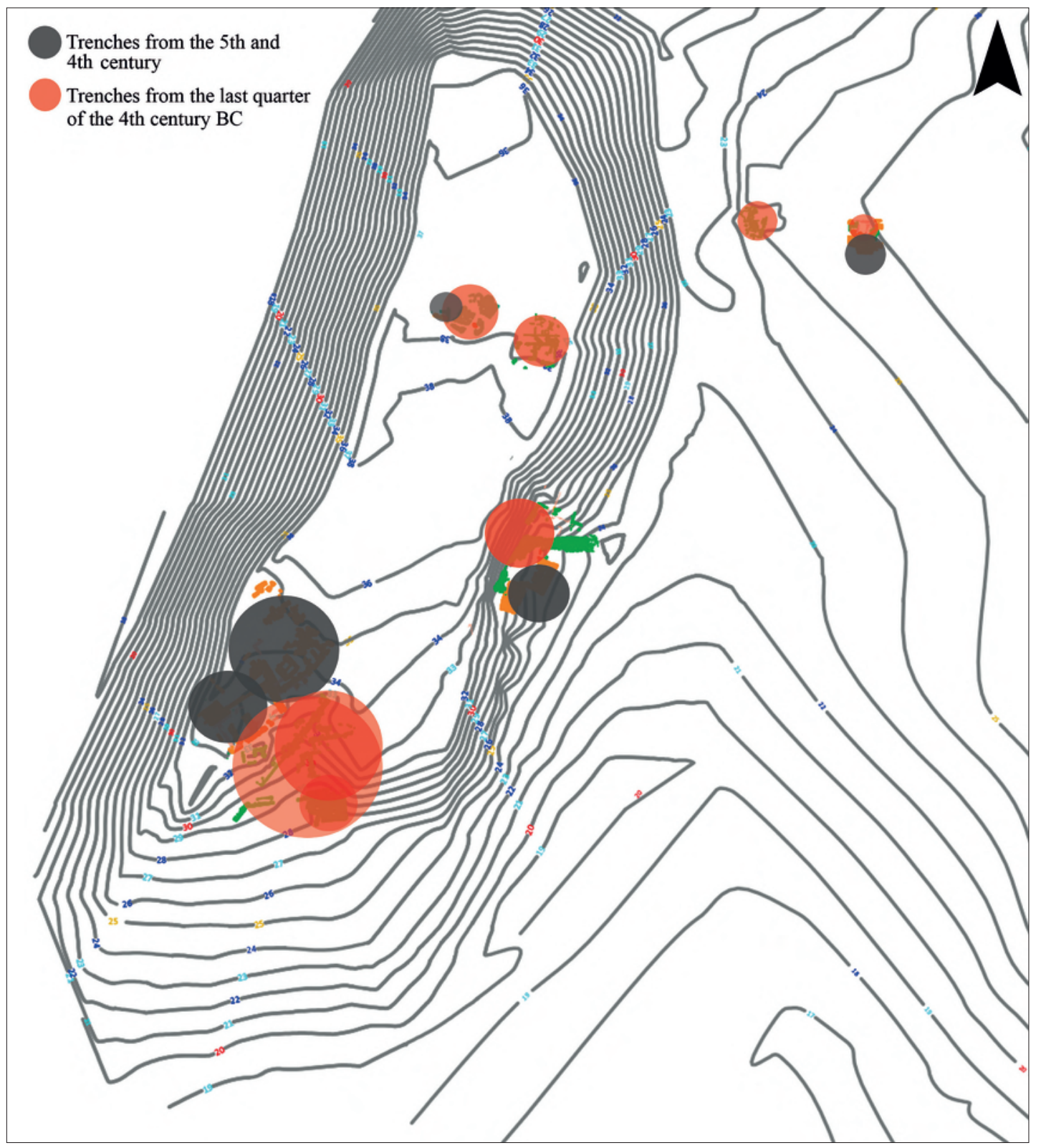

FIG. 13 5th and 4th centuries BC trenches at Daskyleion. 